\title{
Seasonal Variation and Sources of Elements in Urban Submicron and Fine Aerosol in Brno, Czech Republic
}

\author{
Hana Cigánková ${ }^{1,2 *}$, Pavel Mikuška², Jitka Hegrová3 ${ }^{3}$ Petra Pokorná4, \\ Jaroslav Schwarz ${ }^{4}$, Jozef Krajčovič ${ }^{1}$
}

\begin{abstract}
${ }^{1}$ Institute of Chemistry and Technology of Environmental Protection, Faculty of Chemistry, Brno University of Technology, Purkyňova 118, 61200 Brno, Czech Republic

2 Department of Environmental Analytical Chemistry, Institute of Analytical Chemistry of the Czech Academy of Sciences, Veveři 97, 60200 Brno, Czech Republic

${ }^{3}$ Division of Sustainable Transport and Road Structures Diagnostics, Transport Research Center, Líšeňská 33a, 63600 Brno, Czech Republic

${ }^{4}$ Department of Aerosol Chemistry and Physics, Institute of Chemical Process Fundamentals of the Czech Academy of Sciences, Rozvojová 2/135, 16502 Prague 6, Czech Republic
\end{abstract}

\section{ABSTRACT}

Seasonal variation and sources of elements bound to urban aerosol were studied. Fine $\left(\mathrm{PM}_{2.5}\right)$ and submicron $\left(\mathrm{PM}_{1}\right)$ aerosol was collected at 2-week campaigns during four seasons in 2018. The total concentration of 21 elements accounted on average for $3.5 \%$ of the total $\mathrm{PM}_{2.5}$ mass concentration and $2.0 \%$ of the total $\mathrm{PM}_{1}$ mass concentration. Seasonal differences in the element concentrations in $\mathrm{PM}_{1}$ and $\mathrm{PM}_{2.5}$ were found. Most elements in both aerosol size fractions had a higher concentration in winter or autumn than in summer or spring. Enrichment factor analysis showed extremely highly enriched $\mathrm{Cd}$, Sb and Se in both fractions. Positive matrix factorization (PMF) analysis revealed 3 sources (residential heating, resuspension and anthropogenic background) for $\mathrm{PM}_{1}$ and 3 sources (residential heating, resuspension and brake abrasion) for $\mathrm{PM}_{2.5}$ aerosol in

\section{OPEN ACCESS} Brno. In addition, health risk assessment of possibly toxic elements was calculated.

Keywords: Particulate matter, Seasonal variation, Sources of elements, ICP-MS, Elements toxicity

Received: September 10, 2020

Revised: November 3, 2020

Accepted: November 6, 2020

\section{INTRODUCTION}

${ }^{*}$ Corresponding Author: cigankova@iach.cz

\section{Publisher:}

Taiwan Association for Aerosol Research

ISSN: $1680-8584$ print

ISSN: 2071-1409 online

Copyright: The Author's institution. This is an open access article distributed under the terms of the Creative Commons Attribution License (CC BY 4.0), which permits unrestricted use, distribution, and reproduction in any medium, provided the original author and source are cited.

Atmospheric aerosol (particulate matter, PM) affects a number of atmospheric processes (for example radiation balance, reduction of visibility and climate changes) and also affects human health (Amit et al., 2013; Zang et al., 2015; Bates et al., 2019; Manousakas et al., 2020). The atmospheric aerosol has been found to be one of the most important ways of spreading elements (Radzi bin Abas et al., 2004; Desboeufs et al., 2005; Amit et al., 2013; Zang et al., 2015; Rushdi et al., 2017). Elements enter to the atmosphere from natural (volcanic eruptions, wind and Earth erosion, forest fires and the sea salts) or anthropogenic (fossil fuels and wood combustion, industrial activities and waste incineration) sources (Allen et al., 2001; Toscano et al., 2005; Qi et al., 2016). They are found in all aerosol size fractions (Finlayson-Pitts and Pitts, 1999; Allen et al., 2001; Ny and Lee, 2011). Their concentration and size distribution are controlled by the nature of emission source (Ottley and Harrison, 1993; Otten et al., 1994; Migon et al., 1997; Gysels and Van Grieken, 1998; Allen et al., 2001; Qi et al., 2016).

The size distribution of particulate matter allows to predict the extent to which elements can be dispersed via atmospheric transport. The potential impact of PM on human is determined by their chemical composition, shape and size (Allen et al., 2001; Galindo et al., 2013). Particle size 
may have a significant influence on a noxiousness of elements bound to the particle. In general, as particle size decreases, the specific surface increases, which makes elements to be absorbed easier on PM (Zhang et al., 2018a). Also, the degree of respiratory penetration and retention depends on particles sizes, smaller the particle, the more it can penetrate and subsequently deposit into lungs, and stay there for longer time (Espinosa et al., 2001; Chen and Lippmann, 2009; Miguel, 2017).

To evaluate the possible health risks of PM, the research of their chemical composition and size distribution is essential (Espinosa et al., 2001; Wang et al., 2005; Miguel, 2017). Therefore, this study aims to determine the concentration of elements in urban aerosol ( $\mathrm{PM}_{2.5}$ and $\mathrm{PM}_{1}$ ) during four seasons and to estimate their origins. An enrichment factor was determined to evaluate anthropogenic versus natural sources of elements in the particles. Positive Matrix Factorization was used to determine more specific sources and their contribution to the element concentrations. In addition, the health assessment risk of elements ( $\mathrm{As}, \mathrm{Cd}, \mathrm{Co}, \mathrm{Cr}, \mathrm{Mn}, \mathrm{Ni}, \mathrm{Pb}, \mathrm{V}$ and $\mathrm{Zn}$ ) with confirmed adverse health effects were calculated.

over 387,298 deaths worldwide (WHO, 2020b).

\section{METHODS}

\section{1 $\mathrm{PM}_{2.5}$ and $\mathrm{PM}_{1}$ Samples Collection}

Samples of urban aerosol in $\mathrm{PM}_{2.5}$ and $\mathrm{PM}_{1}$ size fraction were collected in Brno $\left(49^{\circ} 12^{\prime} 28.27^{\prime \prime} \mathrm{N}\right.$, $\left.16^{\circ} 36^{\prime} 28.00^{\prime \prime} \mathrm{E}\right)$, the Czech Republic. Brno is the second-largest city in the Czech Republic with 370 thousand citizens. It is an industrial, political and economic centre of Moravia (Křmal et al., 2010). Sampling was carried out on the balcony of the Institute of Analytical Chemistry on Veveři Street at the height of $8.9 \mathrm{~m}$ and the distance of $15.6 \mathrm{~m}$ from the road surface (Coufalík et al., 2016). Veverí Street is one of the most critical thoroughfares in Brno, besides heavy traffic in the street, there is an important tram line.

A total amount of 56 urban aerosol samples (28 $\mathrm{PM}_{2.5}$ and $28 \mathrm{PM}_{1}$ samples) were collected during four 2-week campaigns. Sampling took place in February/March, April/May, July and November 2018. Samples of $\mathrm{PM}_{1}$ and $\mathrm{PM}_{2.5}$ aerosol were collected for 48 hours on nitrocellulose filters (airflow rate of $30 \mathrm{~m}^{3} \mathrm{~h}^{-1}$ ) in parallel using two high-volume samplers (DHA-80 and DHA77, Digitel, Switzerland). 14 samples were collected (7 $\mathrm{PM}_{2.5}$ and $7 \mathrm{PM}_{1}$ samples) in each campaign; 4 samples over the weekend and 10 samples during a working week. Nitrocellulose membrane filters (150 mm diameter, $3 \mu \mathrm{m}$ porosity, Sartorius, Germany) were before and after sampling equilibrated in a clean climatic room at relative humidity $50 \%( \pm 2 \%)$ and $21^{\circ} \mathrm{C}\left( \pm 1^{\circ} \mathrm{C}\right)$ for 48 hours. Equilibrated filters were weighed on M5P microbalance ( $\pm 1 \mu \mathrm{g}$, Sartorius, Germany) equipped with a special large plate to allow weighing of $150 \mathrm{~mm}$ filters (Křumal et al., 2010). Filters with collected PM after weighting were divided into four equal pieces with the ceramic knife on a PTFE plate. Each piece was individually weighed and then sealed in Petri dishes with Parafilm and stored in a refrigerator at $4{ }^{\circ} \mathrm{C}$ before analysis. Three unsampled filters were analyzed along with the samples as process blanks for each campaign.

The sampling campaigns were performed under different atmospheric conditions during different seasons of 2018: winter (12 February-1 March), spring (18 April-2 May), summer (923 July) and autumn (15-29 November). Meteorological parameters (temperature and relative humidity) were observed for each campaign using commercial sensors (type T3113, Comet System, Czech Republic). The analysis of air masses transported towards the sampling site was performed using the Hysplit model v5.0.0 (Stein et al., 2015; Rolph et al., 2017). One-day backward trajectories calculated for 300, 750, $1500 \mathrm{~m}$ above ground level are shown in Supplementary Materials (Fig. S1-S4) separately for each day during all campaigns. The average values of temperature, humidity and predominant wind directions (according to backward trajectories) are shown in Table S1.

\subsection{Analytical Procedures}

\subsubsection{Decomposition of filters}

One-quarter of each filter was decomposed in an UltraWAVE microwave mineraliser (MA 149010, Milestone) in $3 \mathrm{~mL}$ of sub-boiling $\mathrm{HNO}_{3}$ for $25 \mathrm{~min}$. The decomposed filters were transferred 
quantitatively along with $7 \mathrm{~mL}$ of deionized water into polyethylene scintillation vials (Kartel, Italy). Those operations were performed in a clean laboratory with HEPA filters. Increased attention was paid to avoid contamination. Glass and Teflon cups were cleaned in boiling $\mathrm{HNO}_{3}$ for at least 12 hours and then leached in deionized water (Coufalík et al., 2016).

\subsubsection{ICP-QQQMS analysis}

Determination of 21 elements was performed using a triple quadrupole inductively coupled plasma mass spectrometer (ICPMS/MS 8800, Agilent Technologies, Germany) with two quadrupoles $(\mathrm{Q} 1, \mathrm{Q} 2)$ and an octupole reaction cell (ORC), in different tune modes (collision/reaction, $\mathrm{He}, \mathrm{O}_{2}$, $\mathrm{NH}_{3}$ ), working in the on mass mode and mass shift mode used to determine selected elements. Especially for the detection of $\mathrm{Cd}$ the reaction with $\mathrm{NH}_{3}$ in $\mathrm{MS} / \mathrm{MS}$ mode was necessary to achieve low detection limits. As, Se and Fe were analyzed in $\mathrm{O}_{2} \mathrm{MS} / \mathrm{MS}$ mode with a mass shift of +16 . The forwarded RF power was $1550 \mathrm{~W}$, carrier gas (Ar) flow rate $1.07 \mathrm{~L} \mathrm{~min}^{-1}$, integration time per isotope was $0.3 \mathrm{~s}$ in all used modes and cell gas flow rates: helium in collision single quadrupole mode: $4 \mathrm{~mL} \mathrm{~min}{ }^{-1}, 4^{\text {th }}$ Cell gas (oxygen in reaction MS/MS mode): $0.29 \mathrm{~mL} \mathrm{~min}^{-1}, 3^{\text {rd }}$ cell gas (ammonium in reaction $\mathrm{MS} / \mathrm{MS}$ mode) + helium: $4 \mathrm{~mL} \mathrm{~min}^{-1} \mathrm{NH}_{3}+1 \mathrm{~mL} \mathrm{~min}{ }^{-1} \mathrm{He}$.

\subsubsection{Calibration standards}

Calibration standards were prepared in a matrix of $2 \% \mathrm{HNO}_{3}$ from a $1.0000 \mathrm{~g} \mathrm{~L}^{-1}$ stock solution of a single element (Analytika Prague, Czech Republic) mixing into one solution in the concentration range of $0-10 \mathrm{mg} \mathrm{L}^{-1}$ for $\mathrm{Na}, \mathrm{Mg}, \mathrm{Ca}, \mathrm{K}, \mathrm{Mn}, \mathrm{Al}, \mathrm{Fe}$ and $0-100 \mu \mathrm{g} \mathrm{L}^{-1}$ for the rest of elements. Calibration curves of all elements were linear in the whole range $\left(R^{2}=0.9994-1.0000\right)$.

Internal standard for elements determination were prepared from commercial $10 \mathrm{mg} \mathrm{L}^{-1}$ mixture of $\mathrm{Bi}, \mathrm{Ge}$, In, $\mathrm{Li}, \mathrm{Sc}, \mathrm{Tb}, \mathrm{Y}$ (Agilent technologies, USA) by dilution in $2 \% \mathrm{HNO}_{3}$ to final concentration $100 \mu \mathrm{g} \mathrm{L}^{-1}$. The tuning solution were prepared from commercial $10 \mathrm{mg} \mathrm{L}^{-1}$ mixture of $\mathrm{Li}, \mathrm{Co}, \mathrm{Y}, \mathrm{Ce}, \mathrm{Mg}$ and $\mathrm{TI}$ (Agilent technologies, USA) to final concentration $1 \mu \mathrm{g} \mathrm{L}^{-1}$ each element in a matrix of $2 \% \mathrm{HNO}_{3}$.

\subsubsection{Quality control}

Trueness of the method was evaluated by use of suitable standard reference materials: SLRS5 River water reference material for trace elements (National Research Council, Canada) and SRM 1640a Trace Elements in Natural Water (National Institute of Standards \& Technology, Gaithersburg, USA), which were periodically included in the sample measurement sequence. Furthermore, a control standard ( $10 \mu \mathrm{g} \mathrm{L}^{-1}$ calibration standard) was measured periodically for instrument stability control. Online monitoring of internal standard solution was used for instrument stability control as well.

SRM 1648a Urban Particulate Matter (National Institute of Standards \& Technology, Gaithersburg, USA), ERM -CZ 120 Fine dust (PM10-like) (JRC European Commission, Belgium) were digested and analyzed at the same conditions as samples for the control of the whole determination process from preparation to determination.

\subsection{Positive Matrix Factorization}

Positive Matrix Factorization (EPA PMF 5.0) was applied to $\mathrm{PM}_{2.5}$ and $\mathrm{PM}_{1}$ elemental composition to obtain source profiles and their contributions. The data matrix was prepared in compliance with the procedure described in Polissar et al. (1998). The relative analytical uncertainty ranged between 5 and $20 \%$. The final matrices had 28 samples and 20 species for both $\mathrm{PM}_{1}$ and $\mathrm{PM}_{2.5}$ included as a total variable and modelled separately. Previously, PMF has been successfully applied to datasets with a limited number of samples (Contini et al., 2014; Diapouli et al., 2017; Kozáková et al., 2019). The model was run several times using a different number of factors and different extra modelling uncertainties to obtain the Qtrue closest to Qtheoretical, to determine the most physically meaningful result and the best diagnostics.

\subsection{Health Risk Assessment}

The corresponding level of cancer risk (CR) or hazard index ( $\mathrm{HI})$ for selected element was determined using the lifetime average daily dose (LADD) or average daily dose (ADD). LADD 
determined the amount of intake per $\mathrm{kg}$ of body weight per day of a pollutant suspected of adverse health effects (U.S. EPA, 1992; Liu et al., 2018). Because of the different effects on the respiratory system the subjects were divided into two groups: children (0-6 years) and adults. The LADD ( $\mathrm{mg} \mathrm{kg}^{-1} \mathrm{~d}^{-1}$ ) was calculated according to the following equation:

$\operatorname{LADD}(A D D)=C \times \frac{I R \times E F \times E D}{B W \times A T}$

where $C\left(\mathrm{mg} \mathrm{m}^{-3}\right)$ is the concentration of the element of interest in PM, IR $\left(\mathrm{m}^{3} \mathrm{~d}^{-1}\right)$ is the inhalation rate, EF (365 d year ${ }^{-1}$ ) is the exposure frequency, ED (years) is the exposure duration, BW (kg) is the body weight) and AT (days) is the average time (AT $T_{c}$ for carcinogens and $A T_{n}$ for non-carcinogens). The parameters used in Eq. (1) are listed in Table 1.

Cancer risk is described as the possibility of occurrence of diseases caused by tumors in the whole lifetime due to the impact of compounds that produce carcinogenic effects. The US Environmental Protection Agency (USEPA) recommends that CR values less than $1 \times 10^{-6}$ are considered as negligible, and values that exceed $1 \times 10^{-4}$ are probably harmful to human. If hazard index $(\mathrm{HI}) \geq 1$, there may be concern about possible non-carcinogenic health effects (U.S. EPA, 1989; Cerón Bretón et al., 2019; Adimalla, 2020). Equations are as below:

$C R=L A D D \times C S F$

$C S F=I U R \times \frac{B W}{I R} \times 1000$

$H I=\frac{A D D}{R f D}$

were CSF $\left(\mathrm{kg} \mathrm{d} \mathrm{mg}^{-1}\right)$ is cancer slope factor, IUR $\left(\mathrm{m}^{3} \mu \mathrm{g}^{-1}\right)$ is inhalation unit risk a reference value reported in the database of the U.S. EPA (U.S. EPA, 2009) and $\mathrm{RfD}\left(\mathrm{mg} \mathrm{kg}^{-1} \mathrm{~d}^{-1}\right)$ is reference dose of each element considered to have no health effects (Cerón Bretón et al., 2019).

\section{RESULTS AND DISCUSSION}

\subsection{Mass Concentration of Aerosol}

Summary of average mass concentrations and their standard deviations for $\mathrm{PM}_{1}$ and $\mathrm{PM}_{2.5}$ aerosol during all campaigns is shown in Table 2. The mass concentration of $\mathrm{PM}_{1}$ and $\mathrm{PM}_{2.5}$ aerosol was two times higher during winter campaign than during summer campaign. Mass concentrations of $\mathrm{PM}_{1}$ aerosol in spring and summer were on average nearly comparable (Table S2) but in autumn the $\mathrm{PM}_{1}$ concentrations were slightly higher than in spring or summer. The $\mathrm{PM}_{2.5}$ concentrations in autumn were higher than in summer or spring but similar to those in winter (Table S3). The variations in PM mass concentration probably result from the changes in the meteorological situation during the campaigns and also depend on the sources of PM

Table 1. List of parameters used in the exposure calculation.

\begin{tabular}{lllll}
\hline Parameter & Acronym & Unit & Child & Adult \\
\hline Inhalation rate & IR & $\mathrm{m}^{3} \mathrm{~d}^{-1}$ & 12 & 16 \\
Bodyweight & $\mathrm{BW}$ & $\mathrm{kg}$ & 18 & 70 \\
Exposure frequency & EF & $\mathrm{d}$ year & 365 & 365 \\
Exposure duration & ED & years & 6 & 30 \\
Average lifetime & ATc & $\mathrm{d}$ & $25550^{\mathrm{a}}$ & $25550^{\mathrm{a}}$ \\
& ATn & $\mathrm{d}$ & $2190^{\mathrm{b}}$ & $10950^{\mathrm{b}}$ \\
\hline
\end{tabular}

aTc corresponds to the typical life expectancy (70 years) in days. ${ }^{b}$ ATn corresponds to the relevant ED multiplied by EF. 
Table 2. Summary of mass concentration of $\mathrm{PM}_{1}$ and $\mathrm{PM}_{2.5}$ in $\mu \mathrm{g} \mathrm{m}^{-3}$.

\begin{tabular}{|c|c|c|c|c|c|c|c|c|}
\hline & \multicolumn{2}{|c|}{ Winter } & \multicolumn{2}{|c|}{ Spring } & \multicolumn{2}{|c|}{ Summer } & \multicolumn{2}{|c|}{ Autumn } \\
\hline & $\mathrm{PM}_{1}$ & $\mathrm{PM}_{2.5}$ & $\mathrm{PM}_{1}$ & $\mathrm{PM}_{2.5}$ & $\mathrm{PM}_{1}$ & $\mathrm{PM}_{2.5}$ & $\mathrm{PM}_{1}$ & $\mathrm{PM}_{2.5}$ \\
\hline average & 21.9 & 30.4 & 11.5 & 16.0 & 9.74 & 12.4 & 15.9 & 24.0 \\
\hline SD & 6.25 & 7.01 & 2.17 & 3.06 & 2.13 & 2.02 & 3.13 & 5.12 \\
\hline $\min$ & 14.5 & 19.7 & 7.92 & 11.4 & 7.19 & 9.34 & 12.0 & 17.9 \\
\hline $\max$ & 32.6 & 42.0 & 13.7 & 20.0 & 13.7 & 15.8 & 20.4 & 29.8 \\
\hline
\end{tabular}

emissions which likely vary seasonally. The $\mathrm{PM}_{1}$ and $\mathrm{PM}_{2.5}$ mass concentrations show strong negative correlation (correlation coefficient for $\mathrm{PM}_{1} \mathrm{r}=-0.80$ and correlation coefficient for $\mathrm{PM}_{2.5} \mathrm{r}=-0.87$ ) with temperature. The temperature changes influence intensity of primary household heating, which probably causes the increased mass concentration of $\mathrm{PM}_{1}$ and $\mathrm{PM}_{2.5}$ aerosol in winter and autumn. Mass concentrations of PM during week-day were not notably different from those of weekends with exceptions of $\mathrm{PM}_{2.5}$ aerosol in spring and $\mathrm{PM}_{1}$ aerosols in summer that are different (Table S4).

To verify representativeness of sampling site, the mass concentrations of $\mathrm{PM}_{2.5}$ for all seasons were compared by Kruskal-Wallis test with $\mathrm{PM}_{2.5}$ mass concentrations observed by Czech Hydrometeorological Institute at four stations of automatic monitoring system in Brno (i.e., stations Cernopolni (Children's Hospital), Uvoz, Lisen, Turany) (CHMI). The comparison proved that the concentrations of $\mathrm{PM}_{2.5}$ aerosol collected on the balcony of the Institute of Analytical Chemistry are comparable with the $\mathrm{PM}_{2.5}$ results of other measuring stations in Brno (Fig. S5). The chosen sampling site is therefore representative for Brno in terms of $\mathrm{PM}_{2.5}$ concentrations. The annual PM2.5 limit value was not exceeded at any measuring station in Brno in 2018 (CHMI).

A comparison of the observed mass concentrations of $\mathrm{PM}_{1}$ in this study with the results of previous studies from the same sampling site in Brno in 2009 and 2010 (Mikuška et al., 2020) and 2016 (Coufalík et al., 2016) found that there are no significant changes in mass concentrations (Table S5). Slightly increased mass concentrations were observed in the winter campaign of 2010 and the summer campaign of 2009 in comparison with data of this study. Lower mass concentrations were found in the winter campaign of 2009 and 2016 and the summer campaign of 2010 (Coufalík, 2016; Mikuška et al., 2020). It is likely that there has been no significant change of air pollution in Brno over the years in terms of the $\mathrm{PM}_{1}$ fraction.

Summer mass concentrations of $\mathrm{PM}_{1}$ and $\mathrm{PM}_{2.5}$ from Brno were similar to summer samples from Elche, Spain (Galindo et al., 2011) but winter mass concentrations of $\mathrm{PM}_{1}$ and $\mathrm{PM}_{2.5}$ in Elche were lower than those found in Brno. Winter and summer concentrations of $\mathrm{PM}_{1}$ (RogulaKozłowska et al., 2019) and PM2.5 (Juda-Rezler et al., 2020) from Warsaw, Poland were similar to those found in Brno. Studies in Milan, Italy (Vecchi et al., 2004) and Zabrze, Poland (RogulaKozłowska et al., 2012; Rogula-Kozłowska et al., 2019) found higher $\mathrm{PM}_{2.5}$ and $\mathrm{PM}_{1}$ mass concentration in summer and winter than in Brno. Therefore, the PM mass concentrations observed at Brno lie in a similar range to those measured at other European cities.

\subsection{Concentrations of Elements in $\mathrm{PM}_{1}$ and $\mathrm{PM}_{2.5}$ Aerosol}

The average total concentration of elements in $\mathrm{PM}_{1}$ and $\mathrm{PM}_{2.5}$ samples, maximum and minimum contents, limits of detection (LOD) and limits of quantification (LOQ) are presented in Table 3.

The sum of analyzed elements detected by ICP-MS represents a small part of the mass of the particulate matter for both fractions accounting on average for $2.0 \%$ in $\mathrm{PM}_{1}$ mass and $3.5 \%$ in $\mathrm{PM}_{2.5}$ mass. The highest contribution of elements to the mass of the $\mathrm{PM}_{1}$ and $\mathrm{PM}_{2.5}$ was observed in spring (3.5\% in $\mathrm{PM}_{1}$ and $5.7 \%$ in $\mathrm{PM}_{2.5}$ ). In other seasons, the contributions of elements to the mass of the particles were comparable $\left(1.5 \%\right.$ in $\mathrm{PM}_{1}$ and $2.9 \%$ in $\mathrm{PM}_{2.5}$ in winter, $1.4 \%$ in $\mathrm{PM}_{1}$ and $3.0 \%$ in $\mathrm{PM}_{2.5}$ in summer, $1.7 \%$ in $\mathrm{PM}_{1}$ and $2.3 \%$ in $\mathrm{PM}_{2.5}$ in autumn). The sum of element concentration in both $\mathrm{PM}_{1}$ and $\mathrm{PM}_{2.5}$ shows a slightly similar trend to that of $\mathrm{PM}$ mass concentration. The lowest sum of element concentration in $\mathrm{PM}_{1}$ and $\mathrm{PM}_{2.5}$ aerosol was in summer, which corresponded with PM mass concentrations. The highest sum of average elements concentration was in spring, but the highest PM mass concentrations were in winter. 


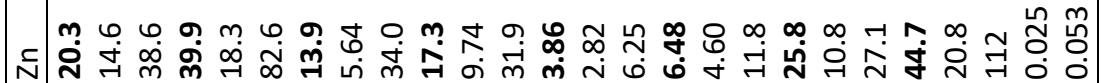
ปิ่

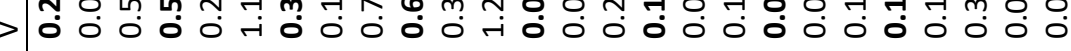

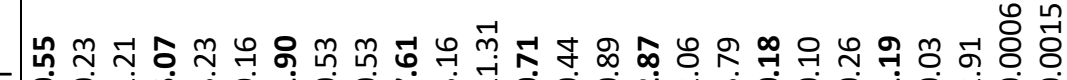
I= Oे

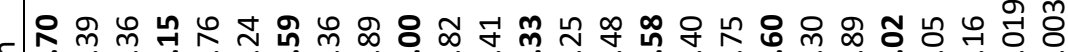

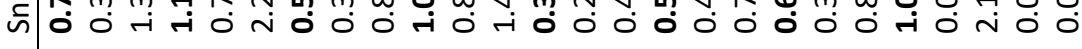
นึㅇㅇ

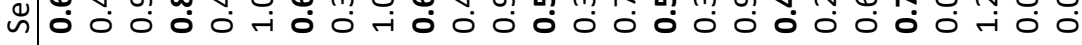

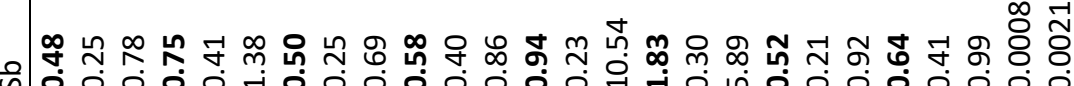

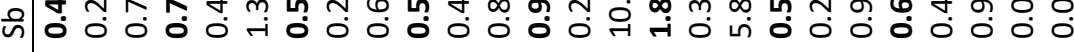

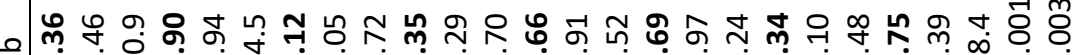

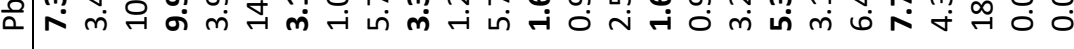

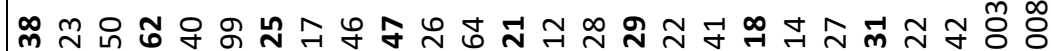
z

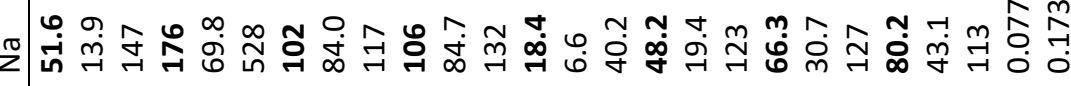

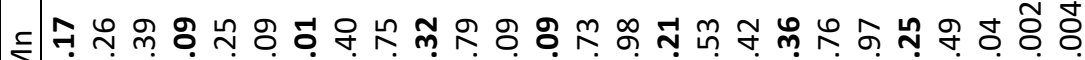
no

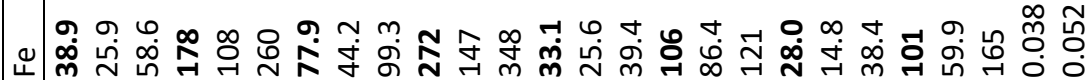

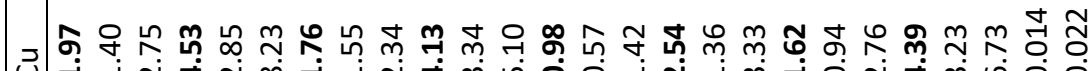

m 웅 0 o

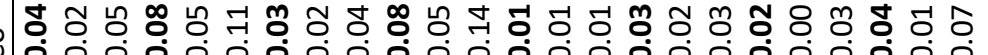

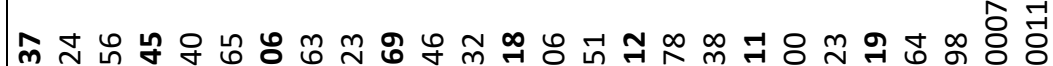

등 궁 ४ 
Elements showed similar seasonal concentration variability, where the concentration of elements originated predominantly from anthropogenic sources (e.g., As, Cd, Cu, K, Pb, Se, Sn and $\mathrm{Zn}$ ) were higher in winter/autumn than in spring/summer and the concentration of elements originated predominantly from natural sources (e.g., $\mathrm{Al}, \mathrm{Ba}, \mathrm{Ca}, \mathrm{Fe}, \mathrm{Mg}$ and $\mathrm{Ti}$ ) were higher in spring/summer than in winter/autumn. Potassium was the most abundant element in both fractions in winter and autumn. The highest level of potassium in these periods is probably due to its primary emission sources - coal combustion and biomass burning (Yu et al., 2018). Emissions from these sources are increasing through the heating season in autumn and winter. The highest average concentrations of $\mathrm{As}, \mathrm{Cd}, \mathrm{Co}, \mathrm{Cu}, \mathrm{Ni}, \mathrm{Pb}$ and $\mathrm{Se}$ for both fractions occurred in winter, and the highest levels of $\mathrm{Cr}$ and $\mathrm{Zn}$ for both fractions occurred in autumn. These elements come mainly from anthropogenic sources like burning fossil fuels, coal combustion, biomass burning, industrial processes, vehicle emissions etc. (Chakraborty and Gupta, 2010; Nordberg et al., 2007). Increased anthropogenic activities (biomass burning, coal combustion, etc.) combined with the low boundary layer, low wind speed and low temperature leading to poor dispersion condition could cause increased concentrations of these elements (Chakraborty and Gupta, 2010).

Increased concentrations of $\mathrm{Al}, \mathrm{Ba}, \mathrm{Ca}, \mathrm{Fe}, \mathrm{Mg}$ and Ti especially for $\mathrm{PM}_{2.5}$ fraction were found, which could indicate resuspension of soil dust in spring. $\mathrm{Al}, \mathrm{Ba}, \mathrm{Fe}, \mathrm{Mg}$ and $\mathrm{Ti}$ comes predominantly from soil dust, and their emission is increased in warmer periods (Rudnick and Gao, 2003; Titos et al., 2014; Nordberg et al., 2007; Sarti et al., 2015; Cheng et al., 2018). For Al, Ba, Ca, Mg and Ti the lowest concentrations were observed in winter or autumn. The highest concentration of $\mathrm{Sb}$ in $\mathrm{PM}_{1}$ and $\mathrm{PM}_{2.5}$ was observed in summer. The observed increase of Sb concentration, especially in $\mathrm{PM}_{1}$ fraction, could be caused by road dust (Titos et al., 2014). Ca and Fe showed increased concentration also during winter, especially in $\mathrm{PM}_{2.5}$ fraction. The concentration of elements originating mainly from the soil dust was probably higher in spring/summer season due to higher wind speed and lower humidity, which resulted in enhanced resuspension of crust.

The comparison of element concentrations found in $\mathrm{PM}_{1}$ and $\mathrm{PM}_{2.5}$ fractions during winter and summer indicated that some elements ( $\mathrm{As}, \mathrm{Cd}, \mathrm{Ni}, \mathrm{Pb}, \mathrm{Se}, \mathrm{Zn}$ ) with primary anthropogenic source (Chung et al., 2014; Zhang et al., 2018b; Mainka and Zahusz-Zubek, 2019) are more often found in the $\mathrm{PM}_{1}$ fraction. $\mathrm{PM}_{1} / \mathrm{PM}_{2.5}$ ratio of $\mathrm{Ni}$ and Se did not exhibit any significant winter/summer seasonal effect but $\mathrm{As}, \mathrm{Cd}, \mathrm{Pb}$ and $\mathrm{Zn} \mathrm{PM} / \mathrm{PM}_{2.5}$ ratio changes during the seasons. These changes were probably caused by different elements sources. Potassium concentrations share of $\mathrm{PM}_{1}$ in $\mathrm{PM}_{2.5}$ appear to be $20-40 \%$ higher during winter and autumn than in summer, which is probably due to emissions from domestic heating (Yu et al., 2018). Al, $\mathrm{Ca}, \mathrm{Fe}, \mathrm{Mg}$, $\mathrm{Na}$ and Ti were present for about $60-90 \%$ in $\mathrm{PM}_{2.5}$ fraction and were probably emitted by natural sources (Kegler et al., 2001; EEA, 2012) or by traffic relative sources (Monaci and Bargagli, 1997).

Elements can originate from several different sources (Mikuška et al., 2020). As and Cd are emitted mainly from coal combustion. Various industrial sources, traffic, biomass burning and coal combustion produced $\mathrm{Ca}, \mathrm{Cu}, \mathrm{Fe}, \mathrm{Mn}, \mathrm{Pb}, \mathrm{Sb}$ or $\mathrm{Zn}$. In addition some elements also originate partly from a municipal solid waste incinerator ( $\mathrm{As}, \mathrm{Cd}, \mathrm{Cu}, \mathrm{Mn}, \mathrm{Ni}, \mathrm{Pb}, \mathrm{Sb}, \mathrm{Sn}, \mathrm{V}$ and $\mathrm{Zn}$ ) located at the east end of sampling site in Brno, incineration of waste in households $(\mathrm{Cd}, \mathrm{Cu}, \mathrm{Pb}, \mathrm{Sb}, \mathrm{Sn}$, $\mathrm{Ti}$ and $\mathrm{Zn}$ ) or cement plant (As, $\mathrm{Ca}, \mathrm{Cd}, \mathrm{Cu}, \mathrm{Fe}, \mathrm{Mn}, \mathrm{Ni}, \mathrm{Pb}$ and $\mathrm{Zn}$ ) located east of Brno (Hu et al., 2003; Conesa et al., 2011; Gupta et al., 2012; Titos et al., 2014; Arfala et al., 2018; Rovira et al., 2018; Horák et al., 2019; Mikuška et al., 2020).

The concentrations of elements found in $\mathrm{PM}_{1}$ samples in this study are comparable with those (Table S6) found in other studies in Brno (Coufalík et al., 2016; Mikuška et al., 2020). The concentration of potassium was comparable to the concentrations from 2009 and 2010 for summer samples, in winter the potassium concentration for 2018 was higher than for 2009 but lower than for 2010. The major differences in the concentration were observed for $\mathrm{Ba}$ and $\mathrm{Pb}$. Both of these elements had lower concentrations in 2018 than in samples from 2009 and 2010 but lead concentrations in 2018 and 2014/2015 were comparable. The element concentrations in corresponding seasons were similar predominantly with samples from 2010.

The concentrations of most elements in $\mathrm{PM}_{2.5}$ and $\mathrm{PM}_{1}$ samples (Tables S6-S7) are comparable with the concentrations found in Nanjing (Qi et al., 2016), Karachi (Mansha et al., 2012), Milan (Vecchi et al., 2004), Barcelona (Moreno et al., 2011) but lower than those in Nanjing (Wu et al., 2019), Wuhan (Zhang et al., 2015), Kanpur (Chakraborty and Gupta, 2010), Tito Scalo (Caggiano et al., 2010), Katowice (Rogula-Kozłowska, 2015). 


\subsection{Enrichment Factor}

Enrichment factors (EFs) were determined concerning the content of elements in the Earth's crust to differentiate the anthropogenic and natural origin of the studied elements. EF of an element is based on normalizing an observed element against a crustal concentration of a reference element. The reference element is an element strongly stable in the crust (Rudnick and Gao, 2003). Typical reference elements used in other studies are Al (Zhang et al., 2007; RogulaKozłowska et al., 2012; Sudheer and Rengarajan, 2012; Rogula-Kozłowska et al., 2013a; Barbieri, 2016), Fe (Ghrefat et al., 2011; Coufalík et al., 2016; Blanchard et al., 2018), Mn (Barbieri, 2016) and Ce (Coufalík et al., 2016). EF is calculated using the equation:

$E F_{X}=(X / Y)_{\text {aerosol }} /(X / Y)_{\text {crust }}$

where $(X / Y)_{\text {aerosol }}$ are concentrations of the examined $(X)$ and reference $(Y)$ element in the samples and $(X / Y)_{\text {crust }}$ are average concentrations of the examined and reference element in the Earth crust. Generally, EF < 10 indicates the crustal soil as the predominant origin of the element. Extremely high enrichment by anthropogenic sources is considered at EF > 40 (Ghrefat et al., 2011; Barbieri et al., 2016; Coufalík et al., 2016; Blanchard et al., 2018).

The calculated average EFs from element concentrations determined in $\mathrm{PM}_{1}$ and $\mathrm{PM}_{2.5}$ collected in Brno with iron as the reference element are presented in Fig. 1. High values of EFs observed for $\mathrm{As}, \mathrm{Cd}, \mathrm{Cu}, \mathrm{Pb}, \mathrm{Sb}, \mathrm{Se}, \mathrm{Sn}$, and $\mathrm{Zn}$ indicate that these elements originate primary from anthropogenic sources. The lowest values of $\mathrm{EF}$ were observed for $\mathrm{Al}, \mathrm{Ba}, \mathrm{Ca}, \mathrm{Co}, \mathrm{Mg}, \mathrm{Na}$ and $\mathrm{Ti}$, which indicates negligible contribution of anthropogenic sources and main origin from natural sources.

Although the elements in $\mathrm{PM}_{1}$ emitted predominantly from anthropogenic sources ( $\mathrm{As}, \mathrm{Cd}, \mathrm{Pb}$, $\mathrm{Sb}, \mathrm{Se}, \mathrm{Sn}, \mathrm{Zn}$ ) consistently showed higher EFs than same elements in $\mathrm{PM}_{2.5}$, they both lie within the error limits. EFs of elements originated predominantly from natural sources ( $\mathrm{Al}, \mathrm{Ba}, \mathrm{Ca}, \mathrm{Mg}$ and $\mathrm{Ti}$ ) were higher in $\mathrm{PM}_{2.5}$ fraction than in $\mathrm{PM}_{1}$ fraction. These results indicate the enhanced association of anthropogenic sources of these elements with the submicron fraction (Al-Momani and Shatnawi, 2017; Mohammed et al., 2017).

Comparison of seasonal changes of EF values (Table S8) indicates that for most of the elements (namely $\mathrm{As}, \mathrm{Cd}, \mathrm{Co}, \mathrm{Cu}, \mathrm{K}, \mathrm{Pb}, \mathrm{Se}, \mathrm{Sn}$ and $\mathrm{Zn}$ ) in both fractions, EFs were higher in colder periods. Other elements such as $\mathrm{Al}, \mathrm{Ba}, \mathrm{Ca}, \mathrm{Mg}$ and $\mathrm{Ti}$ with low values of $\mathrm{EFs}$ did not show distinct seasonal trend.

\subsection{Source Identification}

Positive Matric Factorization (PMF) was applied to determine sources contribution to the fine

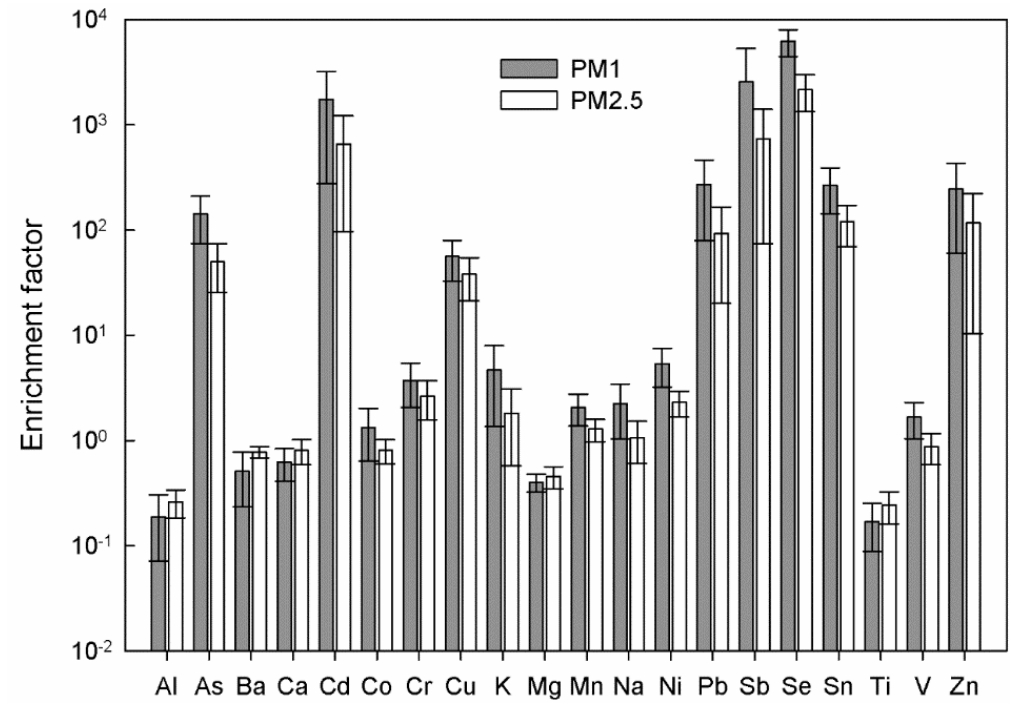

Fig. 1. Average enrichment factors of elements. 
and submicron aerosol fraction. The model was run several times with different factor numbers (3-6) to determine the most physically meaningful result and the best model diagnostics (Table S9). The $Q$ values, the resulting source profiles, and the scaled residuals were examined. The most stable solutions were found for 3 factors for both size fractions by extra modelling uncertainties of 3.0 and $9.3 \%$ for $\mathrm{PM}_{2.5}$ and $\mathrm{PM}_{1}$, respectively. The factor chemical profiles and the time-series plots of the estimated contributions from each factor to the $\mathrm{PM}_{2.5}$ and $\mathrm{PM}_{1}$ mass are shown in Figs. 2 and 3.

The first factor common for both fractions, residential heating, was associated with high concentrations of $\mathrm{K}, \mathrm{Zn}, \mathrm{Pb}$ and As that originate predominantly from coal and biomass combustion for the domestic heating (Rogula-Kozłowska et al., 2013b; Hovorka et al., 2015; Samek et al., 2017; Pokorná et al., 2018). In Brno, gas or electricity is mainly used for residential heating. Coal and wood combustions are used for heating only in $0.46 \%$ of houses in Brno, whereas up to $11 \%$ of houses in small villages nearby Brno use coal and wood for residential heating (Křmal et al., 2010, 2013, 2015; Mikuška et al., 2017). Increased concentrations of K, Zn, Pb and as thus probably result from the regional transport of PM from the villages surrounding Brno. We calculated oneday backward trajectories for all sampling campaigns to test this hypothesis (Figs. S1-S4). Analysis of trajectories proved the transport of air masses from all directions, although during individual campaigns certain wind directions prevailed (Table S1). The elements in the residential heating factor showed strong correlation (Pearson correlation coefficient $r=0.82$ ) and clear seasonal trend with winter maxima in both fractions. Residential heating dominated in the $\mathrm{PM}_{1}$ with an average contribution of $53 \%\left(\mathrm{PM}_{2.5} 44 \%\right)$.

The second factor common for both sizes was ascribed to resuspension of road dust dominated by Earth's crust elements (Mooibroek et al., 2011; Bressi et al., 2014; Diapouli et al., 2017). Resuspension of dust and road wear related particles are the primary contributors to traffic nonexhaust emissions (Keuken et al., 2010). Since the sampling site is located near the road with tram traffic, the road dust also includes particles related to tram rail wear such as $\mathrm{Fe}, \mathrm{Ca}, \mathrm{Al}, \mathrm{Mn}$, $\mathrm{Cu}, \mathrm{Ba}, \mathrm{Zn}$ etc. (Abbasi et al., 2013; Švábenská et al., 2016; Minguillón et al., 2018; Gonet and Maher, 2019). Road dust consists of primarily coarse-sized particles; hence the factor contributed by $12 \%$ to $\mathrm{PM}_{2.5}$ and by $1 \%$ to $\mathrm{PM}_{1}$ in average, and the clear seasonal trend with high factor contribution in spring is apparent in $\mathrm{PM}_{2.5}$. The elements in this factor are strongly correlated (Pearson correlation coefficient $r=0.92$ ).

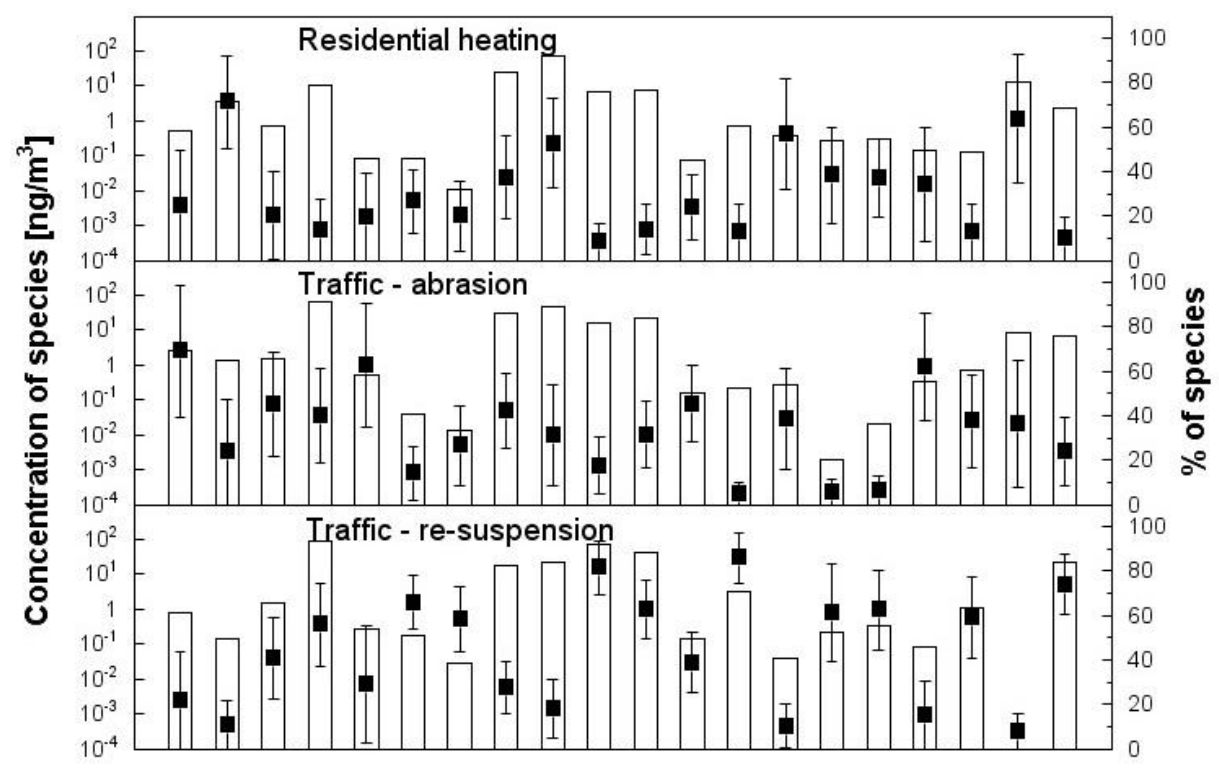

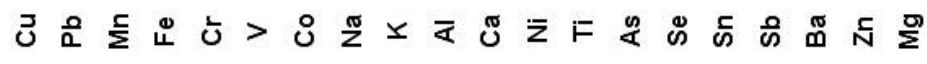

\section{Element}

Fig. 2. Factor profiles (concentration of the species - bars, percentage of the species - markers; DISP Average - box, DISP Max and DISP Min - whiskers) for $\mathrm{PM}_{2.5}$ (left) and $\mathrm{PM}_{1}$ (right) resolve. 


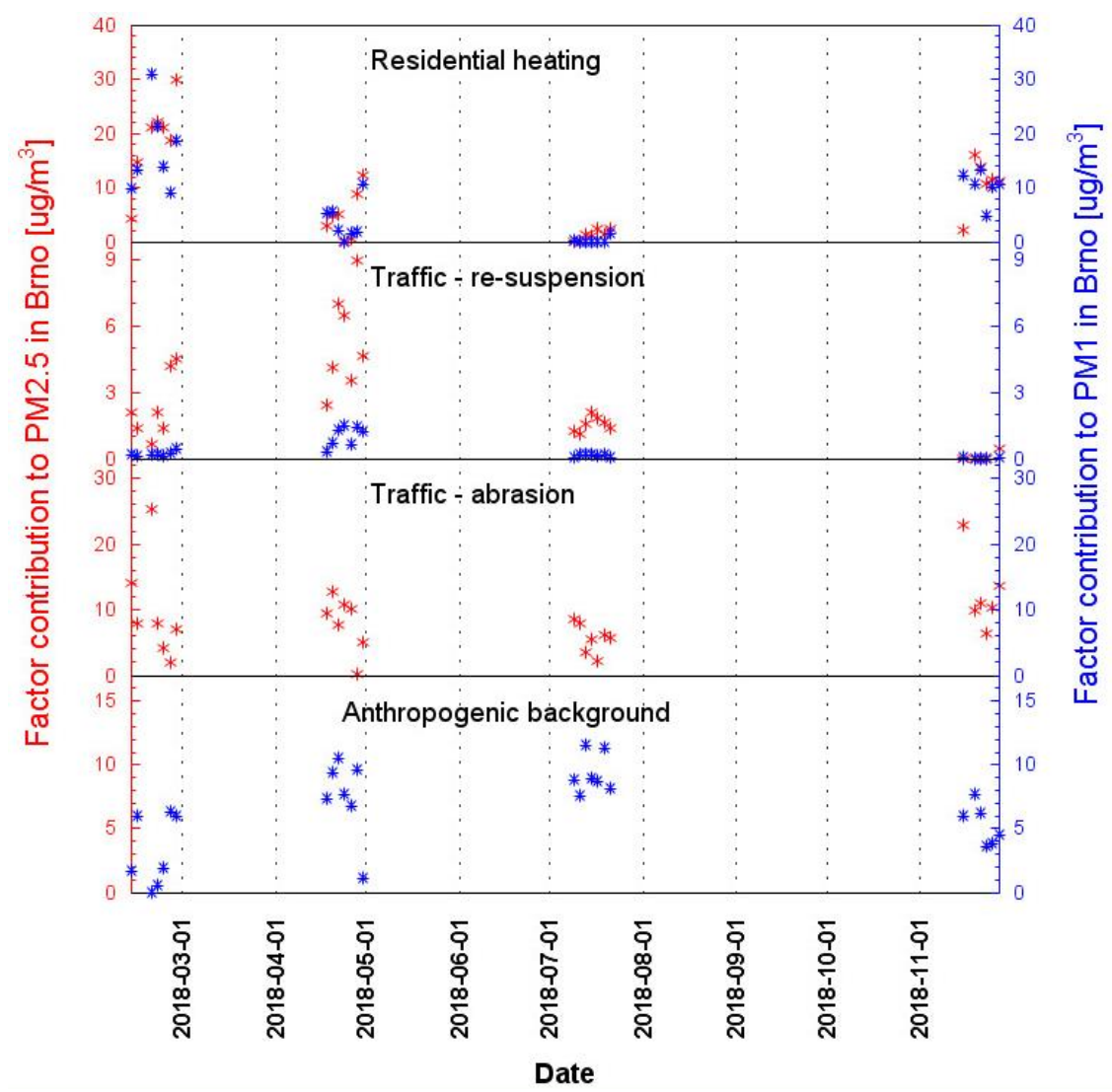

Fig. 3. Factor time series resolved by PMF.

The third factor, abrasion of brakes, represented by $\mathrm{Cu}, \mathrm{Cr}$, Sb (Wahlin et al., 2006; Ondráček et al., 2011; Varrica et al., 2012) was resolved by the model for $\mathrm{PM}_{2.5}$ only with an average contribution of $44 \%$. There is a parking lot under the balcony on which the samplers were placed, also there is a large car sales shop about $\mathbf{4 0}$ meters from the sampling point. Moreover, there is a road junction loaded with frequent traffic jams due to high traffic and two large parking lots approximately 100 meters from the sampling point. Brake wear release PM directly into the atmosphere and contribute to the trace element concentration in airborne PM, particularly less than $10 \mu \mathrm{m}$ (Garg et al., 2000; Wahlin et al., 2006; Gietl et al., 2010; Varrica et al., 2012). The ratio of $\mathrm{Cu}$ and $\mathrm{Sb}(8.0 \pm 0.3)$ as characteristic of brake wear particles was in agreement with study Amato et al. (2011) conducted in at roadside in Barcelona. However, the literature reports differences in $\mathrm{Cu} / \mathrm{Sb}$ ratio attributed to the difference in the brake pad composition and the site characteristics (Pant and Harrison, 2013).

The last factor assigned as the anthropogenic background was related with tracers of traffic as well as local (engineering industry, foundry, municipal waste incinerator) or regional (cement factory) industrial emissions and resolved only for $\mathrm{PM}_{1}$ with the contribution of $45 \%$. Mixed anthropogenic $\mathrm{PM}_{1}$ sources were also identified by Vecchi et al. (2008) in Florence and by Richard et al. (2011) in Zürich. The factor shows a clear seasonal trend with high contributions in spring and summer linked to higher wind speed and mixing conditions in the city. One day backward trajectories (Figs. S1-S4) indicate possible local (i.e., municipal waste incinerator - east wind, foundry - south wind) as well as regional (cement factory - east wind) transport of air masses to sampling site.

The Fig. 3 shows factors contribution to $\mathrm{PM}_{1}$ and $\mathrm{PM}_{2.5}$ in Brno during the seasons. The contribution of residential heating shows a significant dependence on the season, in the colder seasons its contribution increases. The contribution of traffic resuspension to $\mathrm{PM}_{2.5}$ increased slightly in warmer months when the higher average temperatures causes drier conditions leading to enhanced particles resuspension. The contribution of traffic abrasion and anthropogenic background is almost constant throughout the year. 


\subsection{Health Risk Assessment}

The probability of occurrence of cancer ( $\mathrm{CR}$, carcinogenic risk) and hazard index (HI, noncarcinogenic risk) through respiratory system in the exposed human population were calculated for selected elements and two representative groups - children and adults. The lifetime of adults was assumed to 70 years. CR values less than $1 \times 10^{-6}$ are considered as negligible, and values that exceed $1 \times 10^{-4}$ are probably harmful to human health. Hazard index values $(\mathrm{HI}) \geq 1$ may indicate possible non-carcinogenic health effects (U.S. EPA, 1989; Cerón Bretón et al., 2019; Adimalla, 2020). Assessed elements were selected based on their carcinogenic and noncarcinogenic potential for humans (IARC, 1965). The International Agency for Research on Cancer (IARC) classifies substances into several groups. According to this classification, arsenic (As), cadmium ( $\mathrm{Cd}$ ), chromium ( $\mathrm{Cr}$ ), and nickel ( $\mathrm{Ni}$ ) belongs to group 1 (carcinogenic to humans), cobalt (Co) and lead $(\mathrm{Pb})$ belong to group $2 \mathrm{~B}$ (possibly carcinogenic to humans). For this reason, $\mathrm{CR}$ values were calculated only for these elements (IARC, 1965). Moreover, we assessed Mn, V and Zn which induce non-carcinogenic but toxic effects (Zheng et al., 2010; Li et al., 2015).

This study, the CR and HI values (Table 4) were calculated only for inhalation exposure. Carcinogenic and non-carcinogenic health risk of $\mathrm{PM}_{1}$ for both representative groups peaked in winter and summer. The average values of $\mathrm{CR}$ and $\mathrm{HI}$ for adults and children were following the order of $\mathrm{Cr}>\mathrm{As}>\mathrm{Pb}>\mathrm{Cd}>\mathrm{Co}>\mathrm{Ni}$ for the $\mathrm{CR}$ and $\mathrm{Mn}>\mathrm{Cr}>\mathrm{Co}>\mathrm{As}>\mathrm{Pb}>\mathrm{Cd}>\mathrm{Zn}>\mathrm{Cu}>\mathrm{V}$

Table 4. Average cancer risk level and hazard index of carcinogenic and element components of $P M_{1}$ and $P M_{2.5}$ for adult $(A)$ and children $(\mathrm{CH})$.

\begin{tabular}{|c|c|c|c|c|c|c|c|c|c|c|c|c|}
\hline & & & & As & $\mathrm{Cd}$ & Co & $\mathrm{Cr}$ & $\mathrm{Mn}$ & $\mathrm{Ni}$ & $\mathrm{Pb}$ & $\mathrm{V}$ & $\mathrm{Zn}$ \\
\hline \multirow[t]{16}{*}{$\mathrm{PM}_{1}$} & \multirow{8}{*}{ 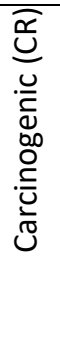 } & \multirow[t]{4}{*}{$\mathrm{CH}$} & winter & 3.7E-07 & $4.9 \mathrm{E}-08$ & $2.9 \mathrm{E}-08$ & $3.38 \mathrm{E}-07$ & & 7.7E-09 & 5.0E-08 & & \\
\hline & & & spring & $1.8 \mathrm{E}-07$ & $1.9 \mathrm{E}-08$ & 8.4E-09 & 4.13E-07 & & 4.3E-09 & $1.2 \mathrm{E}-08$ & & \\
\hline & & & summer & 2.1E-07 & $5.2 \mathrm{E}-09$ & $8.4 \mathrm{E}-09$ & $2.45 \mathrm{E}-07$ & & 4.3E-09 & $1.2 \mathrm{E}-08$ & & \\
\hline & & & autumn & 2.1E-07 & $2.3 \mathrm{E}-08$ & $1.5 \mathrm{E}-08$ & $4.08 \mathrm{E}-07$ & & $3.8 \mathrm{E}-09$ & 3.7E-08 & & \\
\hline & & \multirow[t]{4}{*}{$A$} & winter & $6.4 \mathrm{E}-07$ & $2.5 \mathrm{E}-07$ & $3.6 \mathrm{E}-08$ & $5.8 \mathrm{E}-07$ & & $3.9 \mathrm{E}-08$ & $2.5 \mathrm{E}-07$ & & \\
\hline & & & spring & 3.1E-07 & $9.3 \mathrm{E}-08$ & $2.6 \mathrm{E}-08$ & 7.1E-07 & & $2.6 \mathrm{E}-08$ & 1.1E-07 & & \\
\hline & & & summer & 3.6E-07 & $2.6 \mathrm{E}-08$ & $1.0 \mathrm{E}-08$ & $4.2 \mathrm{E}-07$ & & 2.1E-08 & 5.8E-08 & & \\
\hline & & & autumn & 3.6E-07 & $1.1 \mathrm{E}-07$ & $1.9 \mathrm{E}-08$ & 7.0E-07 & & $1.9 \mathrm{E}-08$ & $1.8 \mathrm{E}-07$ & & \\
\hline & \multirow{8}{*}{ 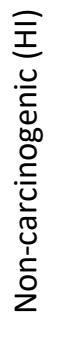 } & \multirow[t]{4}{*}{$\mathrm{CH}$} & winter & $2.2 \mathrm{E}-03$ & $2.1 \mathrm{E}-04$ & $4.4 \mathrm{E}-03$ & 7.7E-03 & $1.0 \mathrm{E}-01$ & $1.2 \mathrm{E}-05$ & $1.4 \mathrm{E}-03$ & $2.3 \mathrm{E}-05$ & 5.7E-05 \\
\hline & & & spring & 1.1E-03 & 8.0E-05 & $3.2 \mathrm{E}-03$ & $9.3 \mathrm{E}-03$ & $9.6 \mathrm{E}-02$ & $8.2 \mathrm{E}-06$ & 5.9E-04 & 3.5E-05 & 3.1E-05 \\
\hline & & & summer & 1.3E-03 & $2.3 \mathrm{E}-05$ & $1.3 \mathrm{E}-03$ & $5.6 \mathrm{E}-03$ & $5.2 \mathrm{E}-02$ & 6.7E-06 & $3.2 \mathrm{E}-04$ & 8.6E-06 & 8.6E-06 \\
\hline & & & autumn & 1.3E-03 & $9.8 \mathrm{E}-05$ & $2.3 \mathrm{E}-03$ & $9.4 \mathrm{E}-03$ & $6.5 \mathrm{E}-02$ & $5.9 \mathrm{E}-06$ & 1.0E-03 & 8.1E-06 & 4.5E-05 \\
\hline & & \multirow[t]{4}{*}{$A$} & winter & 7.6E-04 & 7.3E-05 & $1.5 \mathrm{E}-03$ & $2.6 \mathrm{E}-03$ & $3.5 \mathrm{E}-02$ & $4.2 \mathrm{E}-06$ & $4.8 \mathrm{E}-04$ & 7.7E-06 & $2.0 \mathrm{E}-05$ \\
\hline & & & spring & 3.7E-04 & $2.8 \mathrm{E}-05$ & $1.1 \mathrm{E}-03$ & $3.2 \mathrm{E}-03$ & 3.3E-02 & $2.8 \mathrm{E}-06$ & 2.0E-04 & $1.2 \mathrm{E}-05$ & 1.1E-05 \\
\hline & & & summer & 4.3E-04 & 7.7E-06 & $4.4 \mathrm{E}-04$ & $1.9 \mathrm{E}-03$ & $1.8 \mathrm{E}-02$ & $2.3 \mathrm{E}-06$ & $1.1 \mathrm{E}-04$ & 2.9E-06 & 2.9E-06 \\
\hline & & & autumn & 4.3E-04 & $3.4 \mathrm{E}-05$ & 7.9E-04 & $3.2 \mathrm{E}-03$ & $2.2 \mathrm{E}-02$ & $2.0 \mathrm{E}-06$ & $3.5 \mathrm{E}-04$ & $2.8 \mathrm{E}-06$ & 1.5E-05 \\
\hline \multirow[t]{16}{*}{$\mathrm{PM}_{2.5}$} & \multirow{8}{*}{ 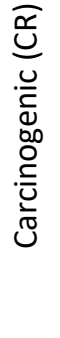 } & \multirow[t]{4}{*}{$\mathrm{CH}$} & winter & 4.7E-07 & 7.5E-08 & $6.3 \mathrm{E}-08$ & $1.0 \mathrm{E}-06$ & & $1.3 \mathrm{E}-08$ & $6.8 \mathrm{E}-08$ & & \\
\hline & & & spring & 2.1E-07 & $2.0 \mathrm{E}-08$ & $6.5 \mathrm{E}-08$ & $1.2 \mathrm{E}-06$ & & 9.7E-09 & $2.3 \mathrm{E}-08$ & & \\
\hline & & & summer & 2.3E-07 & 5.3E-09 & 8.4E-09 & $5.5 \mathrm{E}-07$ & & 4.3E-09 & $1.2 \mathrm{E}-08$ & & \\
\hline & & & autumn & $3.4 \mathrm{E}-07$ & $3.9 \mathrm{E}-08$ & 3.1E-08 & $1.0 \mathrm{E}-06$ & & $6.5 \mathrm{E}-09$ & $5.3 \mathrm{E}-08$ & & \\
\hline & & \multirow[t]{4}{*}{$A$} & winter & 8.1E-07 & 3.7E-07 & $7.8 \mathrm{E}-08$ & $1.8 \mathrm{E}-06$ & & $6.3 \mathrm{E}-08$ & $3.4 \mathrm{E}-07$ & & \\
\hline & & & spring & 3.6E-07 & $9.9 \mathrm{E}-08$ & 8.1E-08 & $2.0 \mathrm{E}-06$ & & $4.9 \mathrm{E}-08$ & 1.1E-07 & & \\
\hline & & & summer & 3.9E-07 & $2.6 \mathrm{E}-08$ & $2.6 \mathrm{E}-08$ & $9.4 \mathrm{E}-07$ & & $3.0 \mathrm{E}-08$ & 5.7E-08 & & \\
\hline & & & autumn & $5.8 \mathrm{E}-07$ & 2.0E-07 & $3.9 \mathrm{E}-08$ & 1.7E-06 & & $3.2 \mathrm{E}-08$ & 2.7E-07 & & \\
\hline & \multirow{8}{*}{ 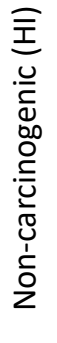 } & \multirow[t]{4}{*}{$\mathrm{CH}$} & winter & $2.8 \mathrm{E}-03$ & $3.2 \mathrm{E}-04$ & $9.5 \mathrm{E}-03$ & $2.4 \mathrm{E}-02$ & 2.4E-01 & 2.0E-05 & 1.9E-03 & 5.0E-05 & 8.9E-05 \\
\hline & & & spring & $1.3 \mathrm{E}-03$ & 8.6E-05 & $9.8 \mathrm{E}-03$ & 2.7E-02 & $2.5 \mathrm{E}-01$ & $1.5 \mathrm{E}-05$ & $6.3 \mathrm{E}-04$ & $6.4 \mathrm{E}-05$ & 3.9E-05 \\
\hline & & & summer & 1.4E-03 & $2.3 \mathrm{E}-05$ & $3.1 \mathrm{E}-03$ & $1.2 \mathrm{E}-02$ & $1.1 \mathrm{E}-01$ & $9.4 \mathrm{E}-06$ & 3.1E-04 & $1.3 \mathrm{E}-05$ & $1.4 \mathrm{E}-05$ \\
\hline & & & autumn & 2.0E-03 & 1.7E-04 & 4.7E-03 & $2.3 \mathrm{E}-02$ & $1.5 \mathrm{E}-01$ & $1.0 \mathrm{E}-05$ & 1.5E-03 & $1.8 \mathrm{E}-05$ & 9.9E-05 \\
\hline & & \multirow[t]{4}{*}{$A$} & winter & 9.7E-04 & $1.1 \mathrm{E}-04$ & 3.3E-03 & 8.1E-03 & 8.3E-02 & $6.8 \mathrm{E}-06$ & $6.4 \mathrm{E}-04$ & 1.7E-05 & 3.0E-05 \\
\hline & & & spring & 4.4E-04 & $2.9 \mathrm{E}-05$ & $3.4 \mathrm{E}-03$ & $9.1 \mathrm{E}-03$ & 8.7E-02 & $5.2 \mathrm{E}-06$ & 2.2E-04 & $2.2 \mathrm{E}-05$ & $1.3 \mathrm{E}-05$ \\
\hline & & & summer & 4.7E-04 & $7.8 \mathrm{E}-06$ & $1.1 \mathrm{E}-03$ & $4.2 \mathrm{E}-03$ & $3.6 \mathrm{E}-02$ & $3.2 \mathrm{E}-06$ & $1.1 \mathrm{E}-04$ & 4.5E-06 & 4.9E-06 \\
\hline & & & autumn & 7.0E-04 & $5.8 \mathrm{E}-05$ & $1.6 \mathrm{E}-03$ & 7.9E-03 & $5.3 \mathrm{E}-02$ & $3.5 \mathrm{E}-06$ & 5.0E-04 & $6.3 \mathrm{E}-06$ & $3.4 \mathrm{E}-05$ \\
\hline
\end{tabular}


$>\mathrm{Ni}$ for the HI. Carcinogenic and non-carcinogenic health risk of $\mathrm{PM}_{2.5}$ for both representative groups showed similar seasonal trend as $\mathrm{PM}_{1}$. The average values of $\mathrm{Cr}$ and $\mathrm{HI}$ for adults and children were following the order of $\mathrm{Cr}>\mathrm{Co}>\mathrm{As}>\mathrm{Pb}>\mathrm{Cd}>\mathrm{Ni}$ for the $\mathrm{CR}$ and $\mathrm{Mn}>\mathrm{Cr}>\mathrm{Co}>$ $\mathrm{As}>\mathrm{Pb}>\mathrm{Cd}>\mathrm{Cu}>\mathrm{Zn}>\mathrm{V}>\mathrm{Ni}$ for the $\mathrm{HI}$. As a result of individual differences (body weight, respiratory rate, exposure duration and average lifetime), the carcinogenic and non-carcinogenic risks to adults and children were different. For both aerosol fraction, the average carcinogenic risks of selected elements were higher for adults than for children but average non-carcinogenic risks were higher for children.

In any season, the upper limit value of $\mathrm{CR}$ or $\mathrm{HI}$ evaluated in $\mathrm{PM}_{2.5}$ or $\mathrm{PM}_{1}$ wasn't exceeded. All $\mathrm{CR}$ values were below value of $1 \times 10^{-6}$, so their effect on human health via inhalation in terms of cancer was negligible. The highest values of $\mathrm{HI}$ were achieved for $\mathrm{Mn}$ (in $\mathrm{PM}_{1} \mathrm{HI}=0.08$ for children and $\mathrm{HI}=0.03$ for adults, in $\mathrm{PM}_{2.5} \mathrm{HI}=0.19$ for children and $\mathrm{HI}=0.06$ for adults), but even these values are lower than the limit value of 1.00 . The obtained results indicate no significant health risk for both representative groups from inhalation exposure to studied elements.

$\mathrm{PM}_{2.5} \mathrm{HI}$ and $\mathrm{CR}$ values of $\mathrm{As}, \mathrm{Cd}, \mathrm{Co}, \mathrm{Cr}, \mathrm{Mn}, \mathrm{Ni}, \mathrm{Pb}, \mathrm{V}$ and $\mathrm{Zn}$ obtained in urban and rural site of Shandong province (Zhang et al., 2018c), Nanjing (Hu et al., 2012) and Chengdu (Li et al., 2016) were higher than those in Brno. $\mathrm{PM}_{2.5} \mathrm{HI}$ values of $\mathrm{Pb}$ and $\mathrm{Zn}$ found in Shangai (Huang et al., 2018) and CR values of As, Cd, Ni found in Tianjin (Chen et al., 2015) were comparable to values in Brno but $\mathrm{HI}$ of $\mathrm{Mn}$ (Chen et al., 2015; Huang et al., 2018), Pb and $\mathrm{Zn}$ (Huang et al., 2018) were lower than in Brno.

\section{CONCLUSIONS}

The average mass concentrations of $\mathrm{PM}_{2.5}$ and $\mathrm{PM}_{1}$ aerosol collected in Brno during four seasons within 2 -week campaigns were $20.8 \pm 8.1 \mu \mathrm{g} \mathrm{m}^{-3}$ and $14.8 \pm 5.4 \mu \mathrm{g} \mathrm{m}^{-3}$. The aerosol mass concentrations were the highest in winter and lowest in summer. The comparison of observed $\mathrm{PM}_{2.5}$ mass concentrations with results from another measuring stations in Brno proved the chosen sampling site as representative for Brno. In 2018, the annual PM2.5 limit value was not exceeded at any measuring station in Brno.

High values of enrichment factors (EF > 40) were observed for $\mathrm{As}, \mathrm{Cd}, \mathrm{Pb}, \mathrm{Sb}, \mathrm{Se}, \mathrm{Sn}$ and $\mathrm{Zn}$. Therefore, the primary sources of these elements were considered to be anthropogenic. The lowest values of EFs observed for $\mathrm{Al}, \mathrm{Ba}, \mathrm{Ca}, \mathrm{Mg}$ and $\mathrm{Ti}$ indicated that these elements originated primarily from soil resuspension. In both fractions, the highest average annual concentration was found for $\mathrm{K}$ and the lowest average concentration for $\mathrm{Co}$. The dependence of element concentrations in $\mathrm{PM}_{1}$ and $\mathrm{PM}_{2.5}$ on season was proved except for $\mathrm{Se}$ and $\mathrm{Ni}$, whose concentrations were similar during all campaigns 2018. The highest concentrations of elements originated mostly from anthropogenic sources were found in winter and autumn and elements which probably originate from resuspension of Earth's crust peaked in spring and summer.

PMF resolved three factors for both PM fractions with two common sources identified as residential heating and road dust resuspension. The high contribution of residential heating to $\mathrm{PM}_{1}$ and $\mathrm{PM}_{2.5}$ proved the significant influence of wood and coal combustion in small villages surrounding Brno on air pollution in the sampled locality. The second main source of PM pollution was traffic resuspension which was a dominant source of $\mathrm{PM}_{2.5}$ aerosol. The abrasion of brakes was identified as the third source for the $\mathrm{PM}_{2.5}$ fraction and the anthropogenic background was identified as the third source for the $\mathrm{PM}_{1}$ fraction. The health risk assessment values of cancer risk and health index didn't overcome a critical value, which indicates that the concentrations of As, $\mathrm{Cd}, \mathrm{Co}, \mathrm{Cr}, \mathrm{Mn}, \mathrm{Ni}, \mathrm{Pb}, \mathrm{V}$ and $\mathrm{Zn}$ were at safe level during all campaigns in 2018.

\section{ACKNOWLEDGEMENT}

The work was supported by the Brno University of Technology, Faculty of Chemistry under the project FCH-S-20-6446, by project No. REG LO1211 from the National Programme for Sustainability I (MEYS CR), by the Grant Agency of the Czech Republic under project No. 104/19/12109S and 503/20/02203S, by the Ministry of Education, Youth and Sports of the Czech Republic under the grant ACTRIS-CZ, LM2018122, by Ministry of Education Youth and Sports 
within the National Sustainability Programme I, project of Transport R\&D Centre (LO1610).

\section{DISCLAIMER}

The authors declare that they have no known competing financial interests or personal relationships that could have appeared to influence the work reported in this paper.

\section{SUPPLEMENTARY MATERIAL}

Supplementary data associated with this article can be found in the online version at https://doi.org/10.4209/aaqr.2020.09.0556

\section{REFERENCES}

Abbasi, S., Jansson, A., Sellgren, U., Olofsson, U. (2013). Particle emission from rail traffic: A literature review. Crit. Rev. Environ. Sci. Technol. 43, 2511-2544. https://doi.org/10.1080/106 43389.2012.685348

Adimalla, N. (2020). Heavy metals contamination in urban surface soils of Medak province, India, and its risk assessment and spatial distribution. Environ. Geochem. Health. 42, 59-75. https://doi.org/10.1007/s10653-019-00270-1

Al-Momani, I.F., Shatnawi, W.M. (2017). Chemical characterization and source determination of trace elements in $\mathrm{PM}_{2.5}$ and $\mathrm{PM}_{10}$ from an Urban Area, Northern Jordan. Int. J. Environ. Monit. Anal. 5, 103-108. https://doi.org/10.11648/j.ijema.20170504.12

Allen, A.G., Nemitz E., Shi, J.P., Harrison R.M., Greenwood, J.C. (2001). Size distribution of trace metals in atmospheric aerosol in the United Kingdom. Atmos. Environ. 35, 4581-4591. https://doi.org/10.1016/S1352-2310(01)00190-X

Amato, F., Viana, M., Richard, A., Furger, M., Prévôt, A.S.H., Nava, S., Lucarelli, F., Bukowiecki, N., Alastuey, A., Reche, C., Moreno, T., Pandolfi, M., Pey, J., Querol, X. (2011). Size and timeresolved roadside enrichment of atmospheric particulate pollutants. Atmos. Chem. Phys. 11, 2917-2931. https://doi.org/10.5194/acp-11-2917-2011

Amit, S.S., Maind, S.D., Tushar, K., Jai, K., Satish, B.A. (2013). Influence of atmospheric aerosol on health and environment-climate change. Int. J. Live Sci. 2019, 115-120.

Arfala, Y., Douch, J., Assabbane, A., Kaaouachi, K., Tian, H., Hamdani, M. (2018). Assessment of heavy metals released into the air from the cement kilns co-burning waste: Case of Oujda cement manufacturing (Northeast Morocco). Sustainable Environ. Res. 28, 363-373. https://doi.org/10.1016/j.serj.2018.07.005

Barbieri, M. (2016). The importance of enrichment factor (EF) and geoaccumulation index (Igeo) to evaluate the soil contamination. J. Geol. Geophys. 5, 1. https://doi.org/10.4172/23818719.1000237

Bates, J.T., Fang, T., Verma, V., Zeng, L., Weber, R.J., Tolbert, P.E., Abrams, J.Y., Sarnat, S.E., Klein, M., Mulholland, J.A., Russell, A.G. (2019). Review of acellular assays of ambient particulate matter oxidative potential: methods and relationships with composition, sources, and health effects. Environ. Sci. Technol. 53, 4003-4019. https://doi.org/10.1021/acs.est.8b03430

Blanchard, D.G., Louis, N.E., Abdourahimi, Daniel, B., Saïdou, Emmanuel, J.N.N. II, Boniface, K., Godfroy, K.N.M. (2018). Environmental pollution by heavy metals in the gold mining region of east cameroon. Am. J. Environ. Sci. 14, 212-225. https://doi.org/10.3844/ajessp.2018.212.225

Bressi, M., Sciare, J., Ghersi, V., Mihalopoulos, N., Petit, J.E., Nicolas, J.B. Moukhtar, S., Rosso, A., Feron, A., Bonnaire, N., Poulakis, E., Theodosi, C. (2014). Sources and geographical origins of fine aerosols in Paris (France). Atmos. Chem. Phys. 14, 8813-8839. https://doi.org/10.5194/a cp-14-8813-2014

Caggiano, R., Macchiato, M., Trippetta, S. (2010). Levels, chemical composition and sources of fine aerosol particles $\left(\mathrm{PM}_{1}\right)$ in an area of the Mediterranean basin. Sci. Total Environ. 408, 884895. https://doi.org/10.1016/j.scitotenv.2009.10.064

Cerón Bretón, J.G., Cerón Bretón, R.M., Espinosa Guzman, A.A., Guarnaccia, C., Martínez Morales, 
S., del Carmen Lara Severino, R., Rangel Marrón, M., Hernández López, G., Carranco Lozada, S.E., Kahl, J.D.W., Pech Pech, I.E., Ramírez Lara, E., de la Luz Espinosa Fuentes, M. (2019). Trace metal content and health risk assessment of $\mathrm{PM}_{10}$ in an urban environment of León, Mexico. Atmosphere 10, 573. https://doi.org/10.3390/atmos10100573

Chakraborty, A., Gupta, T. (2010). Chemical characterization and source apportionment of submicron $\left(\mathrm{pm}_{1}\right)$ aerosol in Kanpur region, India. Aerosol Air Qual. Res. 10, 433-445. https://doi.org/10.4209/aaqr.2009.11.0071

Chen, P., Bi, X., Zhang, J., Wu, J., Feng, Y. (2015). Assessment of heavy metal pollution characteristics and human health risk of exposure to ambient $\mathrm{PM}_{2.5}$ in Tianjin, China. Particuology 20, 104-109. https://doi.org/10.1016/j. partic.2014.04.020

Chen, L.C., Lippmann, M. (2009). Effects of metals within ambient air particulate matter (PM) on human health. Inhalation Toxicol. 21, 1-31. https://doi.org/10.1080/08958370802105405

Cheng, X., Huang, Y., Zhang, S.P., Ni, S.J., Long, Z.J. (2018). Characteristics, sources, and health risk assessment of trace elements in $\mathrm{pm}_{10}$ at an urban site in Chengdu, Southwest China. Aerosol Air Qual. Res. 18, 357-370. https://doi.org/10.4209/aaqr.2017.03.0112

CHMI (2018). Czech Hydrometeorological Institute, Tabular Survey 2018. http://portal.chmi.cz/fi es/portal/docs/uoco/isko/tab_roc/2018_enh/pollution_overview/overview_PM2_5_GB.html (accessed 29 July, 2020).

Chung, J.Y., Yu, S.D., Hong, Y.S. (2014). Environmental source of arsenic exposure. J. Prev. Med. Public Health 47, 253-257. https://doi.org/10.3961/jpmph.14.036

Conesa, J. A., Rey, L., Egea, S., Rey, M.D. (2011). Pollutant formation and emissions from cement kiln stack using a solid recovered fuel from municipal solid waste. Environ. Sci. Technol. 45, 5878-5884. https://doi.org/10.1021/es200448u

Contini, D., Cesari, D., Genga, A., Siciliano, M., lelpo, P., Guascito, M.R., Conte, M. (2014). Source apportionment of size-segregated atmospheric particles based on the major water-soluble components in Lecce (Italy). Sci. Total Environ. 472, 248-261. https://doi.org/10.1016/j.scitote nv.2013.10.127

Coufalík, P., Mikuška, P., Matoušek, T., Večeřa, V. (2016). Determination of the bioaccesible fraction of metals in urban aerosol using simulated lung fluids. Atmos. Environ. 140, 469-475. https://doi.org/10.1016/j.atmosenv.2016.06.031

Desboeufs, K.V., Sofikitis, A., Losno, R., Colin, J.L., Ausset, P. (2005). Dissolution and solubility of trace metals from natural and anthropogenic aerosol particulate matter. Chemosphere 58, 195-203. https://doi.org/10.1016/j.chemosphere.2004.02.025

Diapouli, E., Manousakas, M., Vratolis, S., Vasilatou, V., Maggos, T., Saraga, D., Grigoratos, T., Argyropoulos, G., Voutsa, D., Samara, C., Eleftheriadis, K. (2017). Evolution of air pollution source contributions over one decade, derived by $\mathrm{PM}_{10}$ and $\mathrm{PM}_{2.5}$ source apportionment in two metropolitan urban areas in Greece. Atmos. Environ. 164, 416-430. https://doi.org/10.10 16/j.atmosenv.2017.06.016

EEA (2012). Particulate matter from natural sources and related reporting under the EU Air Quality Directive in 2008 and 2009. European Environment Agency, Copenhagen, Denmark.

Espinosa, A.J.F., Rodríguez M.T., Barragán de la Rosa, F.J., Sánchez, J.C.J. (2001). Size distribution of metals in urban aerosols in Seville (Spain). Atmos. Environ. 35, 2595-2601. https://doi.org/10.1016/S1352-2310(00)00403-9

Finlayson-Pitts, B.J., Pitts J.N.J. (2000). Chemistry of the upper and lower atmosphere, Academic Press, San Diego. https://doi.org/10.1016/B978-0-12-257060-5.X5000-X

Galindo, N., Varea, M., Gil-Moltó, J., Yubero, E., Nicolás, J. (2011). The influence of meteorology on particulate matter concentrations at an Urban Mediterranean Location. Water Air Soil Pollut. 215, 365-372. https://doi.org/10.1007/s11270-010-0484-z

Galindo, N., Gil-Moltó, J., Varea, M., Chofre, C., Yubero, E. (2013). Seasonal and interannual trends in PM levels and associated inorganic ions in southeastern Spain. Microchem. J. 110, 81-88. https://doi.org/10.1016/j.microc.2013.02.009

Garg, B.D., Cadle, S.H., Mulawa, P.A., Groblicki, P.J., Laroo, C., Parr, G.A. (2000). Brake wear particulate matter emissions. Environ. Sci. Technol. 34, 4463-4469. https://doi.org/10.1021/es001108h

Ghrefat, H.A., Abu-Rukah, Y., Rosen, M.A. (2011). Application of geoaccumulation index and enrichment factor for assessing metal contamination in the sediments of Kafrain Dam, Jordan. Environ. Monit. Assess. 178, 95-109. https://doi.org/10.1007/s10661-010-1675-1 
Gietl, J.K., Lawrence, R., Thorpe, A.J., Harrison, R.M. (2010). Identification of brake wear particles and derivation of a quantitative tracer for brake dust at a major road. Atmos. Environ. 44, 141146. https://doi.org/10.1016/j.atmosenv.2009.10.016

Gonet, T., Maher, B.A. (2019). Airborne, vehicle-derived Fe-bearing nanoparticles in the urban environment: A review. Environ. Sci. Technol. 53, 9970-9991. https://doi.org/10.1021/acs.est. 9 b01505

Gupta, R.K., Majumdar, D., Trivedi, J.V., Bhanarkar, A.D. (2012). Particulate matter and elemental emissions from a cement kiln. Fuel Process. Technol. 104, 343-351. https://doi.org/10.1016/j.f uproc.2012.06.007

Gysels, K., Van Grieken, R. (1999). Field evaluation of a wind tunnel-impactor system for sampling ambient aerosol. J. Aerosol Sci. 30, 639-650. https://doi.org/10.1016/S0021-8502(98)00747-2

Horák, J., Kuboňová, L., Bajer, S., Dej, M., Hopan, F., Krpec, K., Ochodek, T. (2019). Composition of ashes from the combustion of solid fuels and municipal waste in households. J. Environ. Manage. 248, 109269. https://doi.org/10.1016/j.jenvman.2019.109269

Hovorka, J., Pokorná, P., Hopke, P.K., Křůmal, K., Mikuška, P., Píšová, M. (2015). Wood combustion, a dominant source of winter aerosol in residential district in proximity to a large automobile factory in Central Europe. Atmos. Environ. 113, 98-107. https://doi.org/10.1016/ j.atmosenv.2015.04.068

Hu, C.W., Chao, M.R., Wu, K.Y., Chang-Chien, G.P., Lee, W.J., Chang, L.W., Lee, W.S. (2003). Characterization of multiple airborne particulate metals in the surroundings of a municipal waste incinerator in Taiwan. Atmos. Environ. 37, 2845-2852. https://doi.org/10.1016/S1352 2310(03)00208-5

Hu, X., Zhang, Y., Ding, Z., Wang, T., Lian, H., Sun, Y., Wu, J. (2012). Bioaccessibility and health risk of arsenic and heavy metals ( $\mathrm{Cd}, \mathrm{Co}, \mathrm{Cr}, \mathrm{Cu}, \mathrm{Ni}, \mathrm{Pb}, \mathrm{Zn}$ and $\mathrm{Mn}$ ) in TSP and $\mathrm{PM}_{2.5}$ in Nanjing, China. Atmos. Environ. 57, 146-152. https://doi.org/10.1016/j.atmosenv.2012.04.056

Huang, H., Jiang, Y., Xu, X., Cao, X. (2018). In vitro bioaccessibility and health risk assessment of heavy metals in atmospheric particulate matters from three different functional areas of Shanghai, China. Sci. Total Environ. 610-611, 546-554. https://doi.org/10.1016/j.scitotenv.20 17.08.074

International Agency for Research on Cancer (IARC) (1965). IARC Monographs on the Identification of Carcinogenic Hazards to Humans. World Health Organization. https://monographs.iarc.fr/agents-classified-by-the-iarc/

Juda-Rezler, K., Reizer, M., Maciejewska, K., Błaszczak, B., Klejnowski, K. (2020). Characterization of atmospheric $\mathrm{PM}_{2.5}$ sources at a Central European urban background site. Sci. Total Environ. 713, 136729. https://doi.org/10.1016/j.scitotenv.2020.136729

Kegler, S.R., Wilson, W.E., Marcus, A.H. (2001). PM1, intermodal (PM2.5-1) mass, and the soil component of $\mathrm{PM}_{2.5}$ in Phoenix, AZ, 1995-1996. Aerosol Sci. Technol. 35, 914-920. https://doi.org/10.1080/02786820126854

Keuken, M., Denier van der Gon, H., van der Valk, K. (2010). Non-exhaust emissions of PM and the efficiency of emission reduction by road sweeping and washing in the Netherlands. Sci. Total Environ. 408, 4591-4599. https://doi.org/10.1016/j.scitotenv.2010.06.052

Kozáková, J., Pokorná, P., Vodička, P., Ondráčková, L., Ondráček, J., Křůmal, K., Mikuška, P., Hovorka, J., Moravec, P., Schwarz, J. (2019). The influence of local emissions and regional air pollution transport on a European air pollution hot spot. Environ. Sci. Pollut. Res. 26, 16751692. https://doi.org/10.1007/s11356-018-3670-y

Křưmal, K., Mikuška, P., Vojtěšek, M., Večeřa, Z. (2010). Seasonal variations of monosaccharide anhydrides in $\mathrm{PM}_{1}$ and $\mathrm{PM}_{2.5}$ aerosol in urban areas. Atmos. Environ. 44, 5148-5155. https://doi.org/10.1016/j.atmosenv.2010.08.057

Křůmal, K., Mikuška, P., Večeřa, Z. (2013). Polycyclic aromatic hydrocarbons and hopanes in PM1 aerosols in urban areas. Atmos. Environ. 67, 27-37. https://doi.org/10.1016/j.atmosenv.2012 10.033

Křumal, K., Mikuška, P., Večeřa, Z. (2015). Monosaccharide anhydrides, monocarboxylic acids and OC/EC in $\mathrm{PM}_{1}$ aerosols in urban areas in the Czech Republic. Atmos. Pollut. Res. 6, 917-927. https://doi.org/10.1016/j.apr.2015.04.001

Li, H., Wang, J., Wang, Q., Qian, X., Qian, Y., Yang, M., Li, F., Lu, H., Wang, C. (2015). Chemical fractionation of arsenic and heavy metals in fine particle matter and its implications for risk 
assessment: A case study in Nanjing, China. Atmos. Environ. 103, 334-346. https://doi.org/10. 1016/j.atmosenv.2014.12.065

Li, Y., Zhang, Z., Liu, H., Zhou, H., Fan, Z., Lin, M., Wu, D., Xia, B. (2016). Characteristics, sources and health risk assessment of toxic heavy metals in $\mathrm{PM}_{2.5}$ at a megacity of southwest China. Environ. Geochem. Health. 38, 353-362. https://doi.org/10.1007/s10653-015-9722-z

Liu, K., Shang, Q., Wan, C. (2018). Sources and health risks of heavy metals in $\mathrm{PM}_{2.5}$ in a campus in a typical suburb area of Taiyuan, North China. Atmosphere 9, 46. https://doi.org/10.3390/a tmos9020046

Mainka, A., Zajusz-Zubek, E. (2019). PM 1 in ambient and indoor air-urban and rural areas in the Upper Silesian Region, Poland. Atmosphere 10, 662. https://doi.org/10.3390/atmos10110662

Manousakas, M.I., Florou, K., Pandis, S.N. (2020). Source apportionment of fine organic and inorganic atmospheric aerosol in an urban background area in Greece. Atmosphere 11, 330. https://doi.org/10.3390/atmos11040330

Mansha, M., Ghauri, B., Rahman, S., Amman, A. (2012). Characterization and source apportionment of ambient air particulate matter $\left(\mathrm{PM}_{2.5}\right)$ in Karachi. Sci. Total Environ. 425, 176-183. https://doi.org/10.1016/j.scitotenv.2011.10.056

Migon, C., Journel, B., Nicolas, E. (1997). Measurement of trace metal wet, dry and total atmospheric fluxes over the Ligurian Sea. Atmos. Environ. 31, 889-896. https://doi.org/10.101 6/S1352-2310(96)00242-7

Miguel, A.F. (2017). Penetration of inhaled aerosols in the bronchial tree. Med. Eng. Phys. 44, 2531. https://doi.org/10.1016/j.medengphy.2017.03.004

Mikuška, P., Kubátková, N., Křůmal, K., Večeřa, Z. (2017). Seasonal variability of monosaccharide anhydrides, resin acids, methoxyphenols and saccharides in $\mathrm{PM}_{2.5}$ in Brno, the Czech Republic. Atmos. Pollut. Res. 8, 576-586. https://doi.org/10.1016/j.apr.2016.12.018

Mikuška, P., Vojtěšek, M., Křůmal, K., Mikušková-Čampulová, M., Michálek, J., Večeřa, Z. (2020). Characterization and source identification of elements and water-soluble ions in submicrometre aerosols in Brno and Šlapanice (Czech Republic). Atmosphere 11, 688. https://doi.org/10.3390/atmos11070688

Minguillón, M.C., Reche, C., Martins, V., Amato, F., Miguel, E., Capdevila, M., Centelles, S., Querol, X., Moreno, T. (2018). Aerosol sources in subway environments. Environ. Res. 167, 314-328. https://doi.org/10.1016/j.envres.2018.07.034

Mohammed, G., Karani, G., Mitchell, D. (2017). Trace elemental composition in $\mathrm{PM}_{10}$ and $\mathrm{PM}_{2.5}$ collected in Cardiff, Wales. Energy Procedia 111, 540-547. https://doi.org/10.1016/j.egypro.2 017.03.216

Monaci, F., Bargagli, R. (1997). Barium and other trace metals as indicators of vehicle emissions. Water Air Soil Pollut. 100, 89-98. https://doi.org/10.1023/A:1018318427017

Mooibroek, D., Schaap, M., Weijers, E.P., Hoogerbrugge, R. (2011). Source apportionment and spatial variability of $\mathrm{PM}_{2.5}$ using measurements at five sites in the Netherlands. Atmos. Environ. 45, 4180-419. https://doi.org/10.1016/j.atmosenv.2011.05.017

Moreno, T., Querol, X., Alastuey, A., Reche, C., Cusack, M., Amato, F., Pandolfi, M., Pey, J., Richard, A., Prévôt, A.S.H., Furger, M., Gibbons, W. (2011). Variations in time and space of trace metal aerosol concentrations in urban areas and their surroundings. Atmos. Chem. Phys. 11, 94159430. https://doi.org/10.5194/acp-11-9415-2011

Nordberg, G.F. Fowler, B.A, Nordberg, M., Friberg, L.T. (2007). Handbook on the toxicology of metals, third ed. Elsevier, UK. https://doi.org/10.1016/B978-0-12-369413-3.X5052-6

Ny, M.T., Lee, B.K. (2011). Size distribution of airbone particulate matter and associated metallic elements in an urban area of an industrial city in Korea. Aerosol Air Qual. Res. 11, 643-653. https://doi.org/10.4209/aaqr.2010.10.0090

Ondráček, J., Schwarz, J., Ždímal, V., Andělová, L., Vodička, P., Bízek, V., Tsai, C.J., Chen, S.C., Smolík, J. (2011). Contribution of the road traffic to air pollution in the Prague city (busy speedway and suburban crossroads). Atmos. Environ. 45, 5090-5100. https://doi.org/10.1016/ j.atmosenv.2011.06.036

Otten, P., Injuk, J., Van Grieken, R. (1994). Elemental concentrations in atmospheric particulate matter sampled on the North Sea and the English Channel. Sci. Total Environ. 155, 131-149. https://doi.org/10.1016/0048-9697(94)90287-9

Ottley, C.J., Harrison, R.M. (1993). Atmospheric dry deposition flux of metallic species to the 
North Sea. Atmos. Environ. 27, 685-695. https://doi.org/10.1016/0960-1686(93)90187-4

Pant, P., Harrison, R.M. (2013). Estimation of the contribution of road traffic emissions to particulate matter concentrations from field measurements: A review. Atmos. Environ. 77, 7897. https://doi.org/10.1016/j.atmosenv.2013.04.028

Pokorná, P., Schwarz, J., Krejci, R., Swietlicki, E., Havránek, V., Ždímal, V. (2018). Comparison of $\mathrm{PM}_{2.5}$ chemical composition and sources at a rural background site in Central Europe between the years 1993/1994/1995 and 2009/2010: Effect of legislative regulations and economic transformation on the air quality. Environ Pollut. 241, 841-851. https://doi.org/10.1016/j.env pol.2018.06.015

Polissar, A.V., Hopke, P.K., Paatero, P., Malm, W.C., Sisler, J.F. (1998). Atmospheric aerosol over Alaska 2. Elemental composition and sources. J. Geophys. Res. 103, 19045-19057. https://doi.org/10.1029/98JD01212

Qi, L., Chen, M., Ge, X., Zhang, Y., Guo, B. (2016). Seasonal variations and sources of 17 aerosol metal elements in Suburban Nanjing, China. Atmosphere 7, 153. https://doi.org/10.3390/atm os7120153

Radzi bin Abas, M., Oros, D.R., Simoneit, B.R.T. (2004). Biomass burning as the main source of organic aerosol particulate matter in Malaysia during haze episodes. Chemosphere 55, 10891095. https://doi.org/10.1016/j.chemosphere.2004.02.002

Richard, A., Gianini, M.F.D., Mohr, C., Furger, M., Bukowiecki, N., Minguillon, M.C., Lienemann, P., Flechsig, U., Appel, K., DeCarlo, P.F., Heringa, M.F., Chirico, R., Baltensperger, U., Prevot, A.S.H. (2011). Source apportionment of size and time resolved trace elements and organic aerosols from an urban courtyard site in Switzerland. Atmos. Chem. Phys. 11, 8945-8963. https://doi.org/10.5194/acp-11-8945-2011

Rogula-Kozłowska, W., Klejnowski, K., Rogula-Kopiec, P., Mathews, B., Szopa, S. (2012). A study on the seasonal mass closure of ambient fine and coarse dusts in Zabrze, Poland. Bull. Environ. Contam. Toxicol. 88, 722-729. https://doi.org/10.1007/s00128-012-0533-y

Rogula-Kozłowska, W., Klejnowski, K. (2013a). Submicrometer aerosol in rural and urban backgrounds in Southern Poland: Primary and secondary components of $\mathrm{PM}_{1}$. Bull. Environ. Contam. Toxicol. 90, 103-109. https://doi.org/10.1007/s00128-012-0868-4

Rogula-Kozłowska, W., Klejnowski, K., Rogula-Kopiec, P., Blaszczak, B., Mathews, B., Szopa, S. (2013b). Mass size distribution of PM-bound elements at an urban background site: Results of an eight-month study in Zabrze. Rocznik Ochrona Srodowiska 15, 1022-1040.

Rogula-Kozłowska, W. (2015). Chemical composition and mass closure of ambient particulate matter at a crossroads and a highway in Katowice, Poland. Environ. Prot. Eng. 41, 15-29. http://epe.pwr.wroc.pl/2015/2-2015/Rogula-Kozlowska_2-2015.pdf

Rogula-Kozłowska, W., Majewski, G., Widziewicz, K., Rogula-Kopiec, P., Tytła, M., Mathews, B. Ciuka-Witrylak, M. (2019). Seasonal variations of $\mathrm{PM}_{1}$-bound water concentration in urban areas in Poland. Atmos. Pollut. Res. 10, 267-273. https://doi.org/10.1016/j.apr.2018.08.004

Rolph, G., Stein, A., Stunder, B. (2017). Real-time environmental applications and display system: READY. Environ. Modell. Software 95, 210-228. https://doi.org/10.1016/j.envsoft.2017.06.025

Rovira, J., Nadal, M., Schuhmacher, M., Domingo, J.L. (2018). Concentrations of trace elements and PCDD/Fs around a municipal solid waste incinerator in Girona (Catalonia, Spain). Human health risks for the population living in the neighborhood. Sci. Total Environ. 630, 34-45. https://doi.org/10.1016/j.scitotenv.2018.02.175

Rudnick, R.L., Gao, S. (2003). Composition of the continental crust. Treatise Geochem. 3, 1-64. https://doi.org/10.1016/B0-08-043751-6/03016-4

Rushdi, A.I., El-Mubarak, A.H., Lijotra, L., Al-Otaibi, M.T., Qurban, M.A., Al-Mutlaq, K.F., Simoneit, B.R.T. (2017). Characteristics of organic compounds in aerosol particulate matter from Dhahran city, Saudi Arabia. Arabian J. Chem. 10, 3532-3547. https://doi.org/10.1016/j.arabjc. 2014.03.001

Samek, L., Stegowski, Z., Furman, L., Fiedor, J. (2017). Chemical content and estimated sources of fine fraction of particulate matter collected in Krakow. Air Qual. Atmos. Health 10, 47-52. https://doi.org/10.1007/s11869-016-0407-2

Sarti, E., Pasti, L., Rossi, M., Ascanelli, M., Pagnoni, A., Trombini, M., Remelli, M. (2015). The composition of $\mathrm{PM}_{1}$ and $\mathrm{PM}_{2.5}$ samples, metals and their water-soluble fractions in the Bologna area (Italy). Atmos. Pollut. Res. 6, 708-718. https://doi.org/10.5094/APR.2015.079 
Stein, A.F., Draxler, R.R, Rolph, G.D., Stunder, B.J.B., Cohen, M.D., and Ngan, F. (2015). NOAA's HYSPLIT atmospheric transport and dispersion modeling system. Bull. Am. Meteorol. Soc. 96, 2059-2077. https://doi.org/10.1175/BAMS-D-14-00110.1

Sudheer, A.K., Rengarajan, R. (2012). Atmospheric mineral dust and trace metals over urban environment in Western India during Winter. Aerosol Air Qual Res. 12, 923-933. https://doi.org/10.4209/aaqr.2011.12.0237

Švábenská, E., Roupcová, P., Schneeweiss, O. (2016). Changes in structure and phase composition in the surface of tram rail. 25th Anniversary International Conference on Metallurgy and Materials (METAL), Proceedings Paper.

Titos, G., Lyamani, H., Pandolfi, M., Alastuey, A., Alados-Arboledas, L. (2014). Identification of fine $\left(\mathrm{PM}_{1}\right)$ and coarse $\left(\mathrm{PM}_{10-1}\right)$ sources of particulate matter in an urban environment. Atmos. Environ. 89, 593-602. https://doi.org/10.1016/j.atmosenv.2014.03.001

Toscano, G., Gambaro, A., Moret, I., Capodaglio, G., Turetta, C., Cescon, P. (2005). Trace metals in aerosol at Terra Nova Bay, Antarctica. J. Environ. Monit. 7, 1275-1280. https://doi.org/10.1 039/B507337P

U.S. EPA (1989). Risk Assessment Guidance for Superfund Volume I: Human Health Evaluation Manual (Part A). Office of Emergency and Remedial Response U.S. Environmental Protection Agency, Washington, D.C., USA.

U.S. EPA (1992). Guidance for Exposure Assessment. Risk Assessment Forum U.S. Environmental Protection Agency, Washington, D.C., USA.

U.S. EPA (2009). Risk Assessment Guidance for Superfund Volume I: Human Health Evaluation Manual (Part F, Supplemental Guidance for Inhalation Risk Assessment). Office of Superfund Rediation and Technology Innovation Environmental Protection Agency, Washington, D.C., USA.

Varrica, D., Bardelli, F., Dongarra, G., Tamburro, E. (2012). Speciation of Sb in airborne particulate matter, vehicle brake linings and brake pad wear residues. Atmos. Environ. 64, 18-24. https://doi.org/10.1016/j.atmosenv.2012.08.067

Vecchi, R., Marcazzan, G., Valli, G., Ceriani, M., Antoniazzi, C. (2004). The role of atmospheric dispersion in the seasonal variation of $\mathrm{PM}_{1}$ and $\mathrm{PM}_{2.5}$ concentration and composition in the urban area of Milan (Italy). Atmos. Environ. 38, 4437-4446. https://doi.org/10.1016/j.atmose nv.2004.05.029

Vecchi, R., Chiari, M., D’Alessandro, A., Fermo, P., Lucarelli, F., Mazzei, F., Nava, S., Piazzalunga, A., Prati, P., Silvani, F., Valli, G. (2008). A mass closure and PMF source apportionment study on thesub-micron sized aerosol fraction at urban sites in Italy. Atmos. Environ. 42, 2240-2253. https://doi.org/10.1016/j.atmosenv.2007.11.039

Wang X., Sato, T., Xing, B., Tamamura, S., Tao, S. (2005). Source identification, size distribution and indicator screening of airborne trace metals in Kanazawa, Japan. J. Aerosol Sci. 36, 197210. https://doi.org/10.1016/j.aerosci.2004.08.005

Wahlin, P., Berkowicz, R., Palmgren, F. (2006). Characterisation of traffic-generated particulate matter in Copenhagen. Atmos. Environ. 40, 2151-2159. https://doi.org/10.1016/j.atmosenv.2 005.11.049

Wu, L., Luo, X.S., Li, H., Cang, L., Yang, J., Yang, J., Zhao, Z., Tang, M. (2019). Seasonal levels, sources, and health risks of heavy metals in atmospheric $\mathrm{PM}_{2.5}$ from four functional areas of Nanjing City, Eastern China. Atmosphere 10, 419. https://doi.org/10.3390/atmos10070419

Yu, J., Yan, C., Liu, Y., Li, X., Zhou, T., Zheng, M. (2018). Potassium: a tracer for biomass burning in Beijing? Aerosol Air Qual. Res. 18, 2447-2459. https://doi.org/10.4209/aaqr.2017.11.0536

Zang, R.J., Ho, K.F., Shen, Z.X. (2015). The role of aerosol in climate change, the environment, and human health. Atmos. Oceanic Sci. Lett. 5, 156-161. https://doi.org/10.1080/16742834.2012. 11446983

Zhang, F., Wang, Z.W., Cheng, H.R., Lv, X.P., Gong, W., Wang, X.M., Zhang, G. (2015). Seasonal variations and chemical characteristics of $\mathrm{PM}_{2.5}$ in Wuhan, central China. Sci. Total Environ. 518-519, 97-105. https://doi.org/10.1016/j.scitotenv.2015.02.054

Zhang, J., Zhou, X., Wang, Z., Yang, L., Wang, J., Wang, W. (2018c). Trace elements in $\mathrm{PM}_{2.5}$ in Shandong Province: Source identification and health risk assessment. Sci. Total Environ. 621, 558-577. https://doi.org/10.1016/j.scitotenv.2017.11.292

Zhang, K., Chai, F., Zheng, Z., Yang, Q., Zhong, X., Fomba, K.W., Zhou, G. (2018a). Size distribution 
and source of heavy metals in particulate matter on the lead and zinc smelting affected area. J. Environ. Sci. 71, 188-196. https://doi.org/10.1016/j.jes.2018.04.018

Zhang, W., Yu, L., Lu, M., Hutchinson, S.M., Feng, H. (2007). Magnetic approach to normalizing heavy metal concentrations for particle size effects in intertidal sediments in the Yangtze Estuary, China. Environ. Pollut. 147, 238-244. https://doi.org/10.1016/j.envpol.2006.08.003

Zhang, Y., Lang, J., Cheng, S., Li, S., Zhou, Y., Chen, D., Zhang, H., Wang, H. (2018b). Chemical composition and sources of $\mathrm{PM}_{1}$ and $\mathrm{PM}_{2.5}$ in Beijing in autumn. Sci. Total Environ. 630, 72-82. https://doi.org/10.1016/j.scitotenv.2018.02.151

Zheng, N., Liu, J., Wang, Q., Liang, Z. (2010). Health risk assessment of heavy metal exposure to street dust in the zinc smelting district, Northeast of China. Sci. Total Environ. 408, 726-733. https://doi.org/10.1016/j.scitotenv.2009.10.075 